746

С98

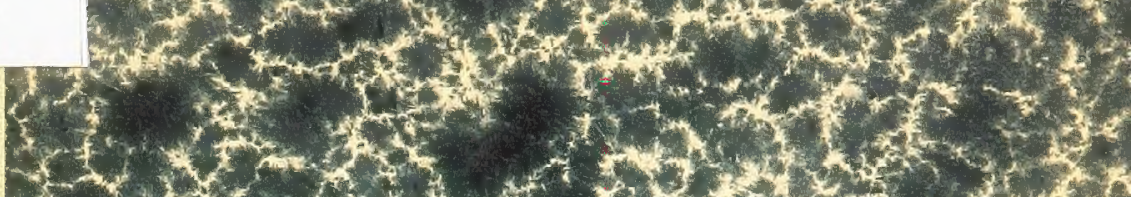

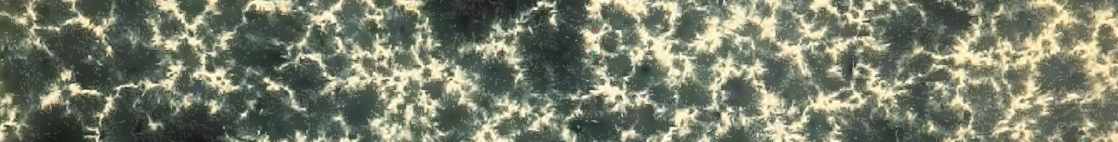

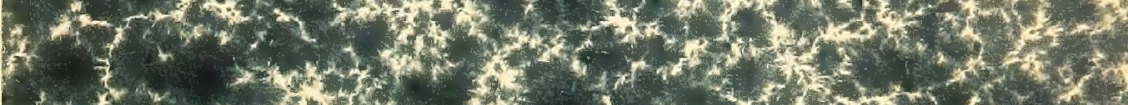

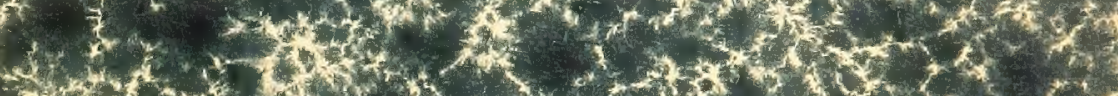

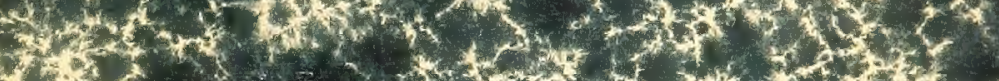

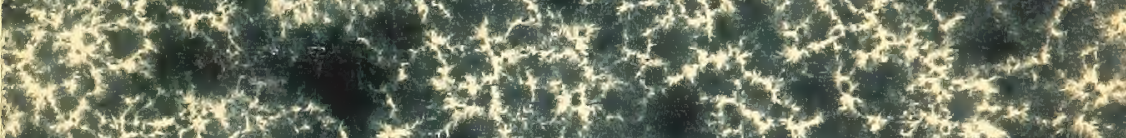

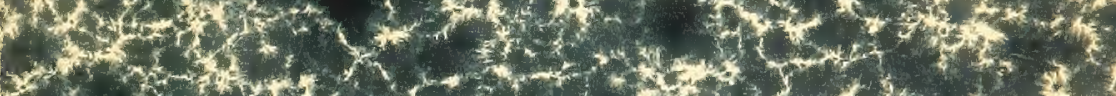

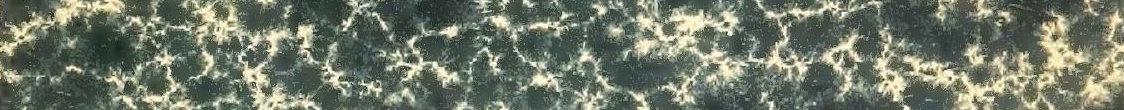

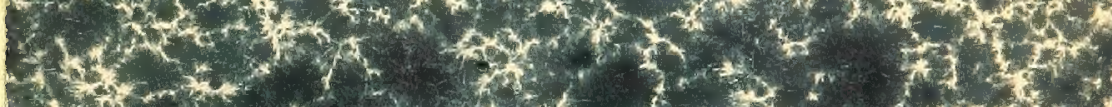

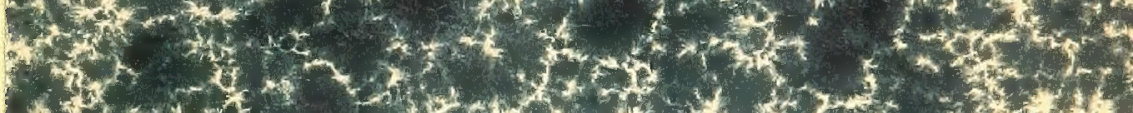

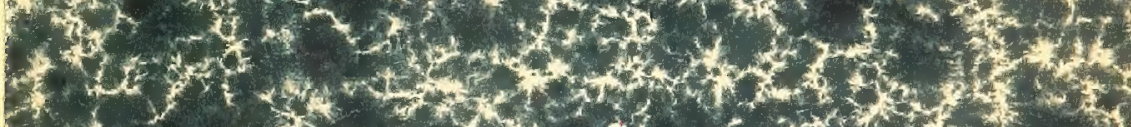

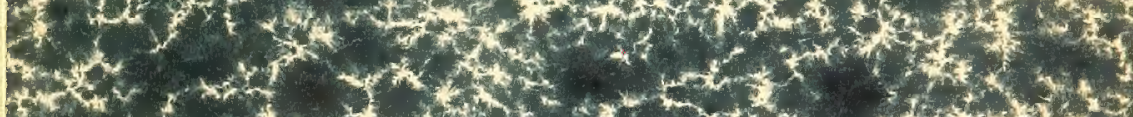

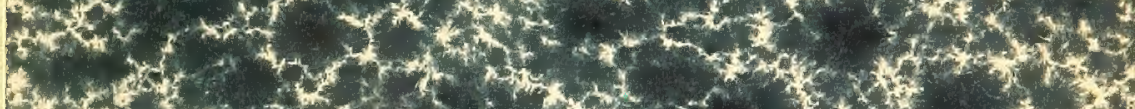

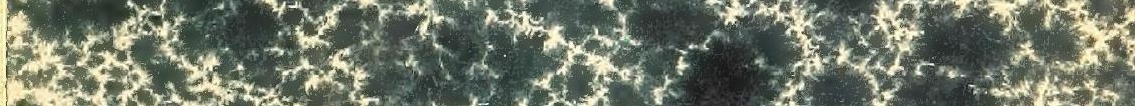

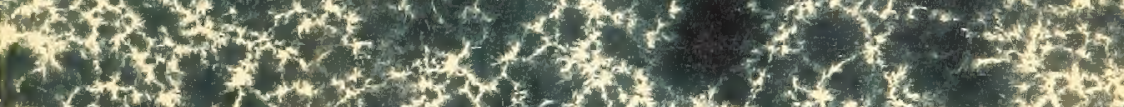

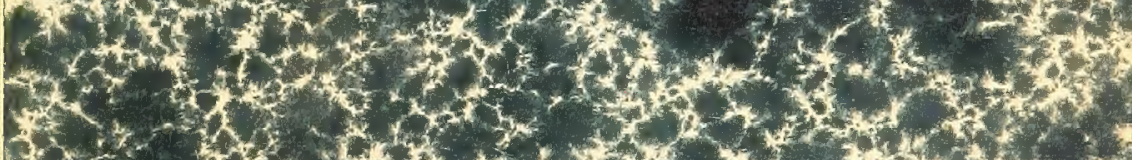

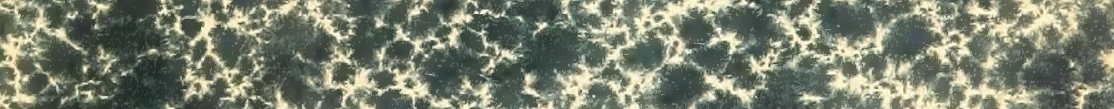

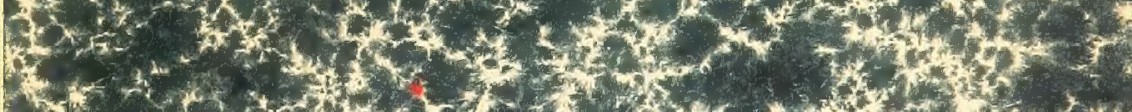

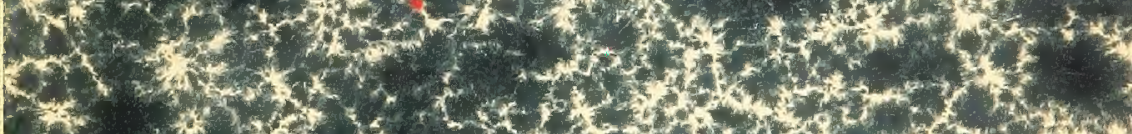

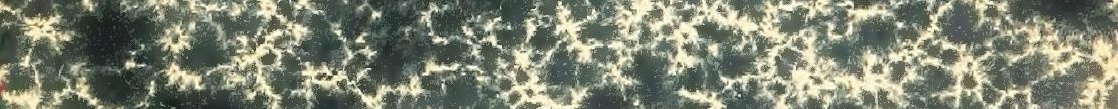

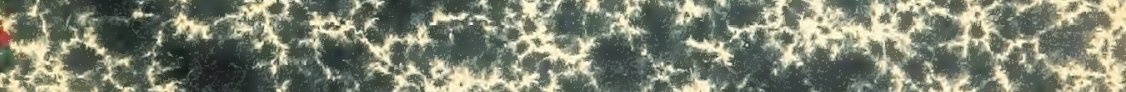

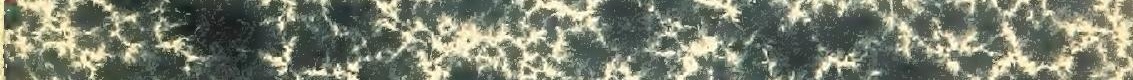

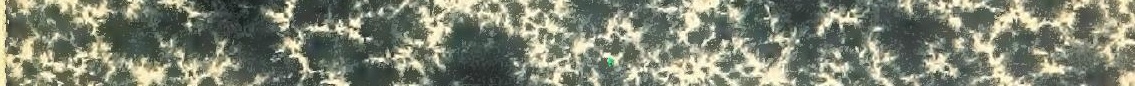

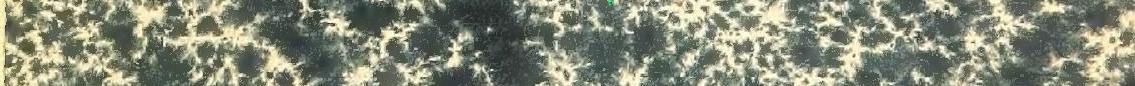

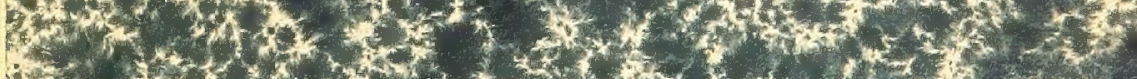

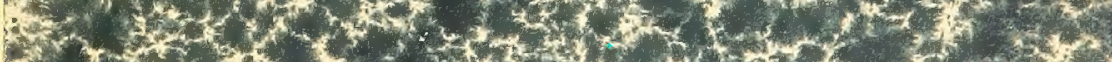

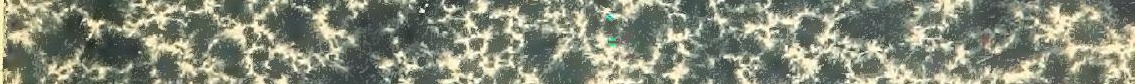

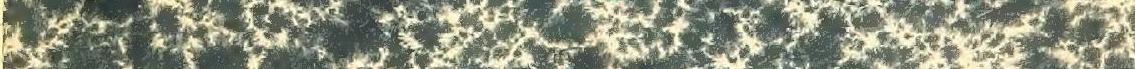

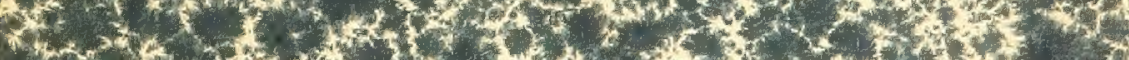

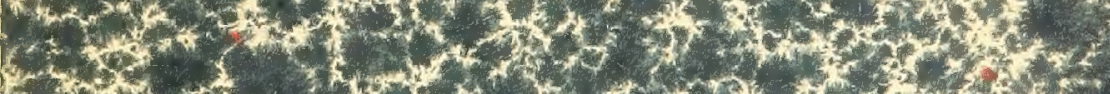

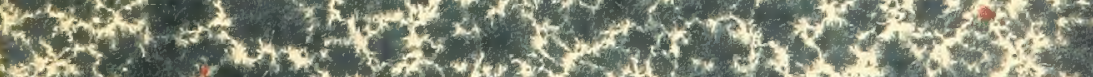

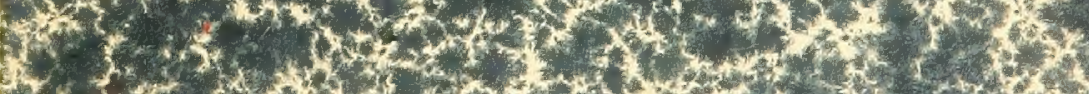




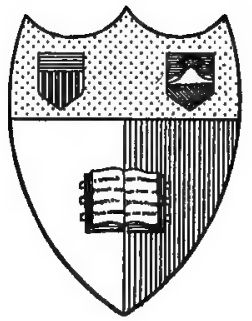

\section{Oramell Anturexity Wihraxy}

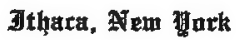




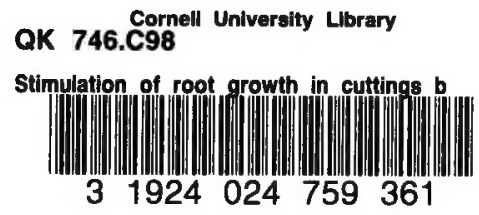




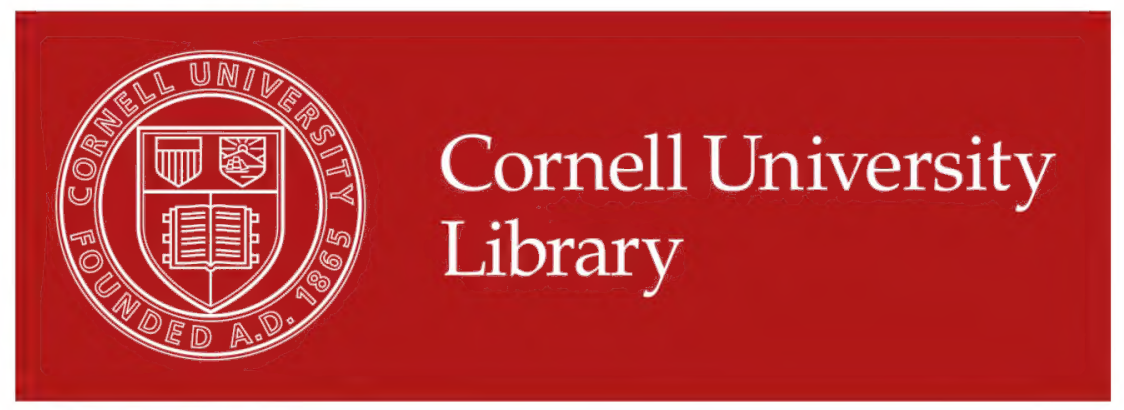

The original of this book is in the Cornell University Library.

There are no known copyright restrictions in the United States on the use of the text.

http://www.archive.org/details/cu31924024759361 

OR CORNELE UNIVERSTY FOR THE DEGREE OR 





\title{
STIMULATION OF ROOT GROWTH IN CUTTINGS BY TREATMENT WITH CHEMICAL COMPOUNDS
}

\author{
A THESIS \\ PRESENTED TO THE FACULTY OF THE GRADUATE SCHOOL \\ OF CORNELL UNIVERSITY FOR THE DEGREE OF \\ DOCTOR OF PHILOSOPHY
}

OTIS F. CURTIS

JUNE, 1916

(Reprinted from Memoir No. 14, August, 1918, of Cornell University Agricultural Experiment Station) 



\section{CONTENTS}

Part I. Effect of inorganie compounds on root growth $\ldots \ldots \ldots \ldots \ldots \ldots \ldots \ldots \ldots$

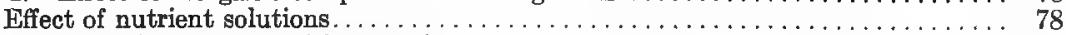

Influence of treatment with potassium permanganate............... 79

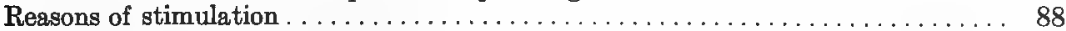

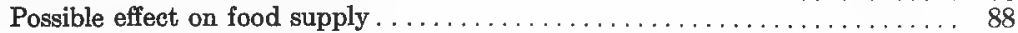

. Relation to rest period $\ldots \ldots \ldots \ldots \ldots \ldots \ldots \ldots \ldots \ldots \ldots \ldots \ldots \ldots \ldots \ldots \ldots$

Effect on rest period of twig as a whole................... 88

Effect on rest period of basal part...................... 91

Stimulation of root growth in twigs that have passed the rest period. . . . . 92

True rest shown only by buds of woody cuttings .............. 93

Possibility that a treatment affecting the rest period may at the same time

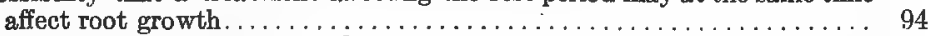

Effect of treatment on correlation between tops and roots .............. 95

Effect of treatment on respiratory activity .................... 97

Effect of treatment on growth of microorganisms................ 100

Comparison of the effect of potassium permanganate with that of other manganese compounds, and also with that of iron, of aluminium, of boron, and of phosphorus . . . . . . . . . . . . . . . . . . . . . . . . . . . . . . . . . . 104

Experiments with herbaceous cuitings. . . . . . . . . . . . . . . . . . . . 104

Experiments with woody cuttings........................... 110

Continuous treatment. . . . . . . . . . . . . . . . . . . . . . . 110

Limited treatment. . . . . . . . . . . . . . . . . . . . . . . . . 110

Discussion of stimulation by compounds other than potassium permanganate.... 111

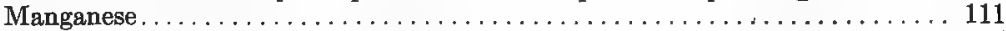

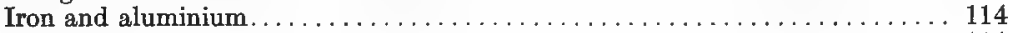

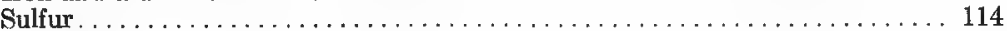

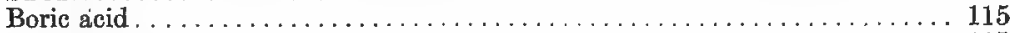

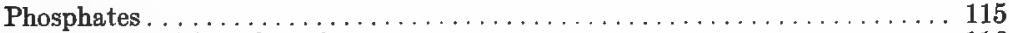

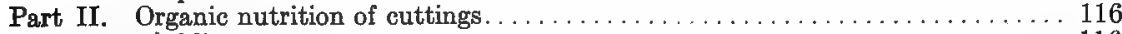

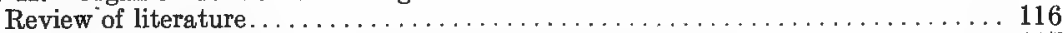

पiffect of limited treatment with sugar solutions on immature twigs . . . . . . . . 117

Treatment with different concentrations . . . . . . . . . . . . . . . . 117

Treatment for one day, for two days, and for twelve days............. 118

Influence of solutions of sugar for one, five, and fourteen days, respectively, in

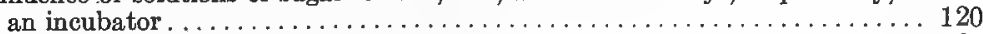

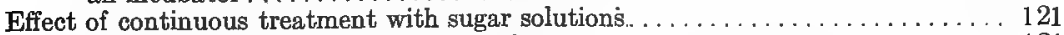

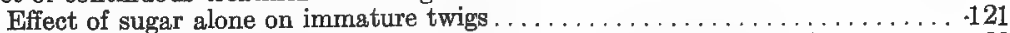

Effect of sugar with manganese dioxide, boric acid, or ferric chloride...... 122

Effect of limited treatment with sugar solutions on maturer cuttings . . . . . . . 123

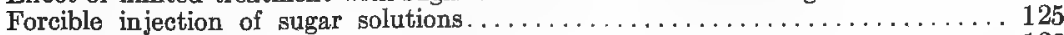

Discussion . .

Part III. General discussion with reference to practices commonly followed by green-

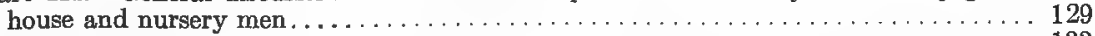

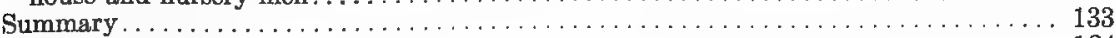

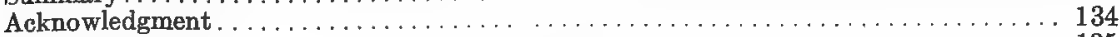

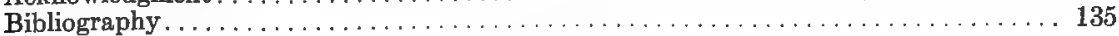



STIMULATION OF ROOT GROWTH IN CUTTINGS BY TREATMENT WITH CHEMICAL COMPOUNDS 



\title{
STIMULATION OF ROOT GROWTH IN CUTTINGS BY TREATMENT WITH CHEMICAL COMPOUNDS ${ }^{1}$
}

\author{
Otis F. Curtis
}

Increasing numbers of plants must of necessity be propagated vegetatively, either because of the difficulties involved in propagation by seed or because many valuable forms do not reproduce true to seed. A large proportion of such plants are started as cuttings, which when placed under suitable conditions will develop into complete plants. In spite of the very general use and importance of this method of propagation, na adequate investigations have thus far been made concerning the principles or the factors involved.

When the importance of propagating plants by cuttings is considered, the value of any treatment that will stimulate root formation in cuttings is obvious. Many special methods of treatment have been suggested. For the most part these are based on practical experience, yet the reasons given for the practices described are often directly conflicting or are not well founded on physiological facts so far as these are known. It would seem, therefore, that some definitely directed research in the physiology of root formation in cuttings would be of value in this field.

During some investigations to determine the effect of various chemical compounds on the rest period of woody plants, conducted in the Laboratory of Plant Physiology at Cornell University, it was found that when twigs of Ligustrum ovalifolium Hassk. were treated for a short time with a solution of potassium permanganate, roots developed to a greater extent than on the checks or on twigs treated with other compounds. These results suggested the possibility of an investigation concerning the effect of various chemical compounds on the root growth of cuttings, and this has been the primary purpose of the present investigation. No experiments have been conducted to compare directly the value of different methods in common practice among propagators, as those methods cover

1 Contribution from the Laboratory of Plant Physiology, Cornell University. 
chiefly the moisture, temperature, and light relations, as well as the effect of the time and manner of making the cuttings. Some of those practices, however, have been briefly discussed in the latter part of this paper, in so far as they are related to the present investigation.

In the experiments conducted by the writer, the cuttings, taken under different conditions as stated for each experiment, were subjected either to a limited or to a continuous treatment with the various compounds used. For limited treatment the time ranged for the most part from one to two days. The cuttings were then rinsed and placed in flasks or in sand. For continuous treatment the cuttings were placed in flasks containing the various compounds dissolved in distilled water, tap water, or full nutrient solution. A few tests were made in which the compounds were applied to sand in pots or flats.and the cuttings were placed directly in these, but no very decided results have thus far been obtained.

For the limited treatments 100 cubic centimeters of solution was used unless otherwise stated. These treatments were administered either in tall glass cylinders, in large test tubes, in flasks, or in tumblers. The cuttings that were left in liquid media were placed in Erlenmeyer flasks of resistance glass, 250 cubic centimeters in capacity. The flasks were carefully cleaned and then covered with black paper. In the majority of cases ten twigs were placed in each container, and the containers were set in trays on benches in the greenhouse. No special precautions were taken for controlling the temperature and the relative humidity. The cuttings in sand were on a greenhouse bench with no bottom heat.

In comparing the relative values of the several treatments, the average total root length per twig was taken as the best criterion. The number of roots and the average length of the individual roots were also determined in some cases, but these figures were not consistent. For example, in a given culture one twig might have a large number of short roots while another had a small number of long roots, and therefore, according to the number of roots, the two would be quite distinctive. The total root length per twig, however, proved to be fairly constant. The total green and dry weights per culture were determined in a few instances. 
In choosing a form with which to experiment, there were several points that had to be considered, as follows:

1. Large numbers of cuttings must be available.

2. The cuttings must be uniform with respect to size, shape, age, position on parent form from which they were taken, and conditions under which they were grown. Otherwise they would be likely to root unevenly.

3. Uniformity in rooting was a very important factor, for without uniformity there was found to be a large probable error which would necessitate the using of great numbers of twigs for each treatment, thereby complicating and increasing the mechanical labor involved. In view of the fact that in these experiments over twelve thousand cuttings of Ligustrum were actually used in addition to four thousand cuttings of other species, it is obvious that the problem would be rendered more difficult if it were necessary to increase the number of cuttings as much as five to ten times.

4. It was important that cuttings should be used which would root in as short a time as possible. The field of research is new, and if one were forced to wait two months or more for results on preliminary tests the experiments would be long drawn out or it would be too late to obtain cuttings for a second set. The writer experienced this trouble for three consecutive years, even with comparatively quick-rooting Ligustrum. On those occasions the December freezes had killed the twigs on the bushes at about the time when the first set of cuttings was showing results. Furthermore, the immature condition of the twigs rendered impossible an earlier beginning of the preliminary experiments. The use of hardy forms would not solve this difficulty, for, tho freezing would not kill the twigs, it would bring them out of the resting condition, which would be detrimental to rooting.

5. It was necessary to choose a form that would root readily. Comparative results could thus be obtained which would allow for manipulation to determine more nearly the optimum treatment.

Ligustrum ovalifolium Hassk. most nearly fitted the requirements outlined, and therefore it was used in the majority of the experiments. The following forms also were used: Cydonia oblonga Mill., Ribes Houghtonianum Janez., Pyrus malus Linn., Prunus cerasifera Ehrh., Kerria japonica DC., Evonymus europaea Linn., Berberis Thunbergii DC., 
Diervilla sp., Populus nigra var. italica Du Roi, Spiraea Vanhouttei Zabel, Forsythia sp., three species of Salix, Iresine Herbstii Hook. f., and Lycopersicum esculentum Mill.

\section{PART I. EFFECT OF INORGANIC COMPOUNDS ON ROOT GROWTH}

\section{EFFECT OF NUTRIENT SOLUTIONS}

In order to be able to follow more closely the development of the roots, it was necessary to grow the cuttings in liquid media. To determine whether a nutrient solution might increase root growth, various strengths of Knop's and Crone's solutions were employed, as indicated in table 1. Cuttings of Ligustrum ovalifolium were taken from two hedges which had been growing under somewhat different conditions. The twigs from one hedge (Column B in table 1) soon produced a strong growth of tops, resulting in such a large increase in transpiration surface and

TAble 1. Efrect of Nutrient Solutions on Root Growth in Woody Cuttings (Continuous treatment from November 21, 1914, to January 8, 1915. Ten twigs to a culture)

\begin{tabular}{|c|c|c|c|}
\hline \multirow[b]{2}{*}{ Solution } & \multicolumn{2}{|c|}{ A } & \multirow{2}{*}{$\begin{array}{c}\text { B } \\
\begin{array}{c}\text { Number } \\
\text { of twigs } \\
\text { rooted }\end{array}\end{array}$} \\
\hline & $\begin{array}{l}\text { Average } \\
\text { total } \\
\text { length of } \\
\text { roots per } \\
\text { twig } \\
\text { (millimeters) }\end{array}$ & $\begin{array}{l}\text { Number } \\
\text { of twigs } \\
\text { rooted }\end{array}$ & \\
\hline 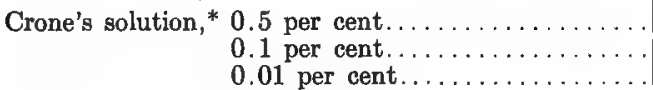 & $\begin{array}{l}\cdots \cdots \cdots \\
\ldots \ldots \cdots \\
\ldots \ldots \ldots\end{array}$ & & $\begin{array}{r}\text { Dead } \\
\text { Dead } \\
5\end{array}$ \\
\hline 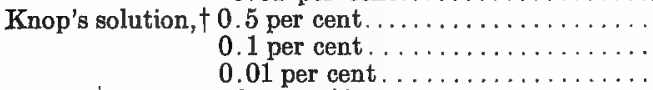 & $\begin{array}{r}\text { Dead } \\
110 \pm 26.4 \\
251 \pm 23.8\end{array}$ & $\begin{array}{r}0 \\
6 \\
10\end{array}$ & $\begin{array}{r}\text { Dead } \\
\text { Dead } \\
4\end{array}$ \\
\hline 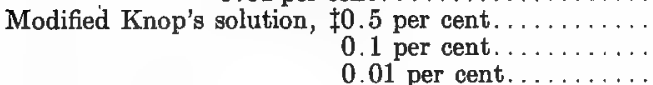 & $\begin{array}{r}\text { Derd } \\
72 \pm 27.5 \\
260 \pm 28.5\end{array}$ & $\begin{array}{r}0 \\
7 \\
10\end{array}$ & $\begin{array}{l}\text { Dead } \\
\text { Dead }\end{array}$ \\
\hline 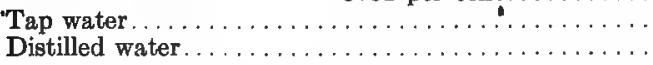 & $\begin{array}{l}218 \pm 26.8 \\
203 \pm 37.5\end{array}$ & $\begin{array}{l}10 \\
10\end{array}$ & 3 \\
\hline
\end{tabular}

*Crone's solution contained salts in the following proportions: $\mathrm{KNO}_{3}, 4 ; \mathrm{CaSO}_{4}, 2 ; \mathrm{MgSO}_{4}, 2$; $\mathrm{Fe}_{2}\left(\mathrm{PO}_{4}\right)_{2}, 1 ; \mathrm{Ca}_{4}\left(\mathrm{PO}_{4}\right)_{2}, 1$.

$+\mathrm{Kn}$ op's solution contained salts in the following proportions: $\mathrm{Ca}\left(\mathrm{NO}_{8}\right)_{2}, 1 ; \mathrm{KNO}_{8}, 0.25 ; \mathrm{MgSO}_{8}, 0.25$; $\mathrm{KH}_{2} \mathrm{PO}_{4}, 0.25 ; \mathrm{Fe}_{2}\left(\mathrm{PO}_{4}\right)_{2}, 0.05$.

- $\ddagger$ The modified Knop's solution was similar to the preceding but contained five times the proportion of iron phosphate. In both cases iron phosphate was used in place of iron chloride. 
in loss of water that the flasks containing them became dry. The twigs in some of the cultures had produced roots. Such cases were noted but no measurements were taken. The twigs from the other hedge (Column A in the table) remained dormant for some time and the buds were just starting at the time when the roots were measured.

It is shown fairly clearly in table 1 that nutrient solutions of the strengths used in culture work with seedlings are distinctly injurious to woody cuttings. This injurious effect of nutrient solutions, especially at the higher concentrations -0.1 per cent or above - was further proved by subsequent experiments in which similar results were obtained. In four experiments, sixteen out of a total of twenty cultures showed distinct retardation of growth on the addition of nutrient solutions. Even single nutrient salts, such as $\mathrm{CaCl}_{2}, \mathrm{NaH}_{2} \mathrm{PO}_{4}, \mathrm{KNO}_{3}$, and $\mathrm{KH}_{2} \mathrm{PO}_{4}$, in very dilute solutions, showed marked retardation of the root growth. No very extensive experiments with nutrient solutions were attempted, since the few results obtained showed clearly that such treatments tend to be more injurious than beneficial to woody cuttings. A few experiments with herbaceous cuttings indicated that these are less injured by concentrations up to 0.2 per cent than are woody forms.

The root development in woody cuttings is usually lessened by an increase in concentration of the nutrient solution, as shown by the figures in table 1. This is somewhat comparable to the effect of high concentrations of soil or nutrient solutions on seedlings observed by a number of investigators - Polle (1910), Harris (1914), Stiles (1915), Brenchley (1916), and many others. The writer has found, however, that woody cuttings are much less tolerant of the stronger concentrations than are seedlings.

A discussion of the causes for increase or decrease of root growth resulting from a change in concentration of nutrient solutions, and reports of further experiments, are reserved for a later paper.

\section{INFLUENCE OF TREATMENT WITH POTASSIUM PERMANGANATE}

As already stated, it was found that twigs of Ligustrum ovalifolium developed more extensive roots when treated with potassium permanganate than when treated with a number of other compounds. Potassium permanganate was therefore tried in the first of these experiments. In 
order to determine the limiting concentrations, as well as the optimum time of treatment, single lots of ten cuttings each of Ligustrum ovalifolium were treated as indicated in table 2:

table 2. Influence of Concentrations and of Duration of Treatment with $\mathrm{KMnO}_{4}$ on CUtTings of Ligustrum ovalifolium

(Cuttings taken on November 29, 1913)

\begin{tabular}{|c|c|c|c|c|}
\hline \multirow[b]{2}{*}{$\begin{array}{l}\text { Solutions used and time of } \\
\text { treatment }\end{array}$} & \multicolumn{4}{|c|}{$\begin{array}{l}\text { Cuttings grown in solutions in flasks, or treated and } \\
\text { placed in tap water. Roots measured January } 14,1914\end{array}$} \\
\hline & $\begin{array}{l}\text { Average total } \\
\text { length of roots } \\
\text { per twig } \\
\text { (millimeters) }\end{array}$ & $\begin{array}{l}\text { Average total } \\
\text { length of roots } \\
\text { relative to } \\
\text { check as unity }\end{array}$ & $\begin{array}{c}\text { Average } \\
\text { number } \\
\text { of roots } \\
\text { to the } \\
\text { twig }\end{array}$ & $\begin{array}{l}\text { Average } \\
\text { length } \\
\text { per root } \\
\text { (milli- } \\
\text { meters) }\end{array}$ \\
\hline Check . . . . . . . . . . . . . & $88.4 \pm 18.7$ & $1.00 \pm 0.21$ & 8.8 & 10.0 \\
\hline \multicolumn{5}{|l|}{ Treatment 24 hours } \\
\hline $\mathrm{KMnO}_{4}, 2$ per cent. . . . . . & $361.4 \pm 31.9$ & $4.09 \pm 0.36$ & 15.2 & 23.8 \\
\hline 1 per cent........ & $317.0 \pm 15.0$ & $3.59 \pm 0.17$ & 13.9 & 22.8 \\
\hline 0.5 per cent. & $276.0 \pm 36.5$ & $3.12 \pm 0.41$ & 10.8 & 25.6 \\
\hline \multicolumn{5}{|l|}{ Treatment 5 days } \\
\hline $\mathrm{KMnO}_{4}, 0.50$ per cent. . . . & $234.0 \pm 31.2$ & $2.65 \pm 0.35$ & 9.6 & 24.3 \\
\hline 0.25 per cent. . . . . & $217.0 \pm 30.6$ & $2.45 \pm 0.35$ & 11.8 & 18.5 \\
\hline 0.10 per cent. . . . . & $60.0 \pm 11.0$ & $0.68 \pm 0.12$ & 4.3 & 14.2 \\
\hline 0.05 per cent. . . . & $26.0 \pm 13.9$ & $0.29 \pm 0.16$ & 3.2 & 7.9 \\
\hline \multicolumn{5}{|l|}{ Continuous treatment } \\
\hline $\mathrm{KMnO}_{4}, 0.10$ per cent. . . . & $294.0 \pm 25.0$ & $3.33 \pm 0.28$ & 12.6 & 23.4 \\
\hline 0.05 per cent $\ldots \ldots \ldots$ & $183.0 \pm 14.8$ & $2.07 \pm 0.17$ & 13.3 & 13.8 \\
\hline 0.01 per cent....... & $145.0 \pm 14.5$ & $1.64 \pm 0.17$ & 9.1 & 15.8 \\
\hline 0.005 per cent. . . . . & $176.0 \pm 16.6$ & $1.99 \pm 0.19$ & 10.2 & 17.1 \\
\hline 0.001 per cent. . . . . & $115.0 \pm 21.3$ & $1.30 \pm 0.24$ & 8.5 & 13.5 \\
\hline 0.0001 per cent. & $44.0 \pm 11.5$ & $0.50 \pm 0.13$ & 4.1 & 10.8 \\
\hline
\end{tabular}


TABLE 2 (concluded)

\begin{tabular}{|c|c|c|c|c|}
\hline \multirow[b]{2}{*}{$\begin{array}{c}\text { Solutions used and time of } \\
\text { treatment }\end{array}$} & \multicolumn{4}{|c|}{$\begin{array}{c}\text { Cuttings treated and placed in sand. Roots measured } \\
\text { January } 19,1914\end{array}$} \\
\hline & $\begin{array}{l}\text { Average total } \\
\text { length of roots } \\
\text { per twig } \\
\text { (millimeters) }\end{array}$ & $\begin{array}{l}\text { Average total } \\
\text { length of roots } \\
\text { relative to } \\
\text { check as unity }\end{array}$ & $\begin{array}{c}\text { Average } \\
\text { number } \\
\text { of roots } \\
\text { to the } \\
\text { twig }\end{array}$ & $\begin{array}{l}\text { Average } \\
\text { length } \\
\text { per root } \\
\text { (milli- } \\
\text { meters) }\end{array}$ \\
\hline Check. . . . . . . . . . & 149.0 & & 13.0 & 11.4 \\
\hline Check. & 143.0 & & 11.2 & 12.8 \\
\hline Average of checks $\ldots \ldots \ldots \ldots$ & $146.0 \pm 12.1$ & $1.00 \pm 0.08$ & 12.1 & 12.1 \\
\hline \multicolumn{5}{|l|}{ Treatment 24 hours } \\
\hline $\mathrm{KMnO}_{4}, 2$ per cent $\ldots \ldots \ldots$ & $183.0 \pm 18.5$ & $1.25 \pm 0.13$ & 9.8 & 18.2 \\
\hline 1 per cent $\ldots . . . \ldots$ & $352.0 \pm 15.0$ & $2.41 \pm 0,10$ & 17.3 & 20.4 \\
\hline 0.5 per cent. .... & $211.0 \pm 7.2$ & $1.45 \pm 0.05$ & 14.0 & 15.0 \\
\hline Treatment 5 days & & & & , 41, \\
\hline $\mathrm{KMnO}_{4}, 0.50$ per cent. . . . & $287.0 \pm 20.6$ & $1.97 \pm 0.14$ & 11.4 & 25.2 \\
\hline 0.25 per cent..... & $212.0 \pm 6.6$ & $1.45 \pm 0.05$ & 10.6 & 20.0 \\
\hline 0.10 per cent. . . & $199.0 \pm 22.1$ & $1.36 \pm 0.15$ & 12.0 & 16.6 \\
\hline 0.05 per cent. & $111.0 \pm 12.5$ & $0.76 \pm 0.08$ & 8.0 & 15.3 \\
\hline
\end{tabular}

As shown by table 2 and also by figure 1, potassium permanganate causes a marked stimulation of root growth in Ligustrum in the 24-hours, 5 -days, and continuous treatments. With but one exception the maximum stimulation occurred in the strongest solutions, indicating that higher concentrations might give even better results. Subsequent experiments have shown, however, that concentrations close to the optimum were used in the 24-hours and continuous treatments. The optima in these two gave results of $4.09 \pm 0.36$ and $3.33 \pm 0.28$, respectively, relative to the check as unity. The difference between the check and the best treatment is over eight and a half times the probable error. The cuttings placed in the sand, as shown by the same table, indicated a lesser degree 
of stimulation, but the optimum results show a root growth $2.41 \pm 0.10$ and $1.97 \pm 0.14$ times that of the control. Tho but single cultures were used, and there were only five twigs in the sand cultures - except in the check, in which the number was sixteen - yet the results were unexpectedly consistent, showing a continuous change with change in concentration with one unimportant exception in which the culture having a slight increase in concentration had a somewhat lower root length. In four cases the weakest concentrations gave a root length shorter than

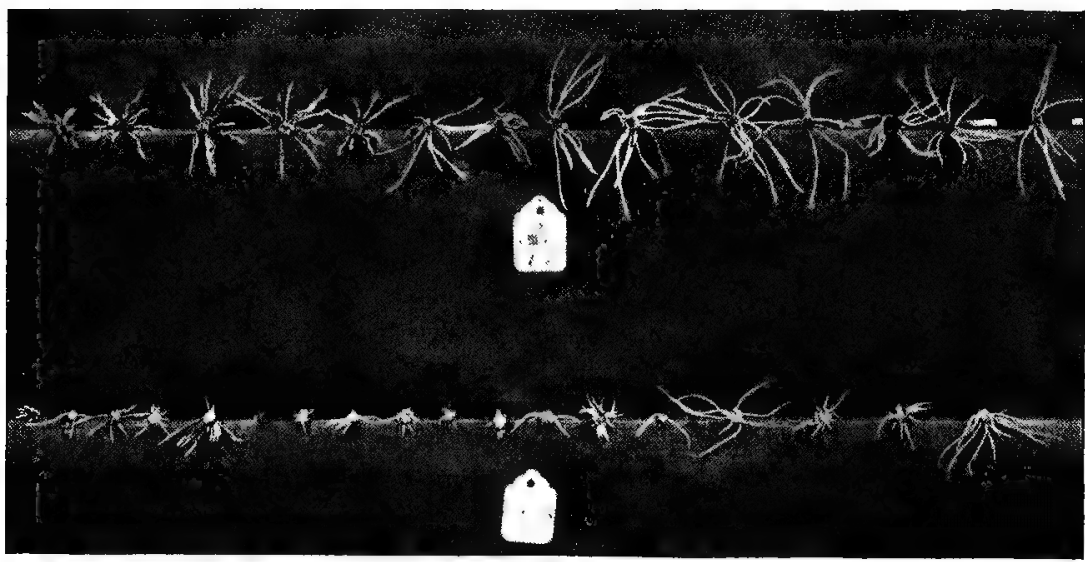

Fig. 1. Ligustrum cuttings as affected by treatment with potassium permanGANATE

Upper row: Cuttings treated for twenty-four hours in 1-per-cent $\mathrm{KMnO}_{4}$; the five at the left then vlaced in sand, the remainder in tap water

Lower row: Check. Cuttings left for twenty-four hours in tap water; the five at the left then placed in sand, the remainder in tap water

that in the check. These dilutions were so great and the results so similar to those of the check that the latter may indicate merely a probable variation between separate checks.

The stimulation here obtained has been fully confirmed by later experiments in which duplicate and triplicate cultures were made, and by others in which one hundred or more twigs were used in each treatment. This table was given in preference to the others, as the single experiment covers a wider range of concentrations and lengths of treatment than any one subsequent experiment. 
In addition to the experiment just reported, Ligustrum was used in nine other experiments in which the cuttings were treated with potassium permanganate. In these experiments, some of which are described later in this paper, there were fifty-two treatments with potassium permanganate at different concentrations, usually in duplicate, and for different lengths of time. All these fifty-two treatments, with the exception of three in which the concentrations were too high, showed stimulation of root growth above that obtained in the checks.

Since Ligustrum was so clearly benefited by the treatment, a few experiments were made to determine whether or not other species would be similarly affected. Some of these experiments were started in the latter part of winter, which proved to be too late for successful rooting. Cuttings of Ribes, Cydonia, and Berberis formed roots and the results seemed to indicate some stimulation, but there was such wide variation between duplicate cultures that no definite conclusions could be drawn.

Treatment with potassium permanganate stimulated root growth in cuttings of a number of woody plants, as is shown in table 3 . With several forms the treatment not only rèsulted in an increase in root length per twig, but also caused a larger proportion of cuttings to take root. The results obtained with Prunus cerasifera are shown in figures 2 and 3.

All the forms here reported can be fairly readily propagated by hardwood cuttings if these are taken at the proper time of year and if sufficient precautions are used in setting and handling them. It is apparent, however, that if the cuttings are taken late in the season and placed in the sand, with no especial precautions regarding the supply of bottom heat, moisture, light, and temperature, a treatment with potassium permanganate results in a marked improvement in root production in respect both to the aggregate length and dry weight of the roots of a given twig and to the proportion of twigs forming roots. In addition to the experiments reported in table 3 , an experiment with Ligustrum shows very clearly this improvement under adverse conditions. Cuttings were taken very late in the season - March 16, 1917. Contrary to the usual practice, the base of each twig was cut square across with rather dull pruning shears and no clean diagonal cut was made with a sharp knife. The twigs were treated as indicated in table 4 and then placed in sand. Because of the lateness of the season and the rather careless treatment, the check twigs failed to develop roots as freely as 


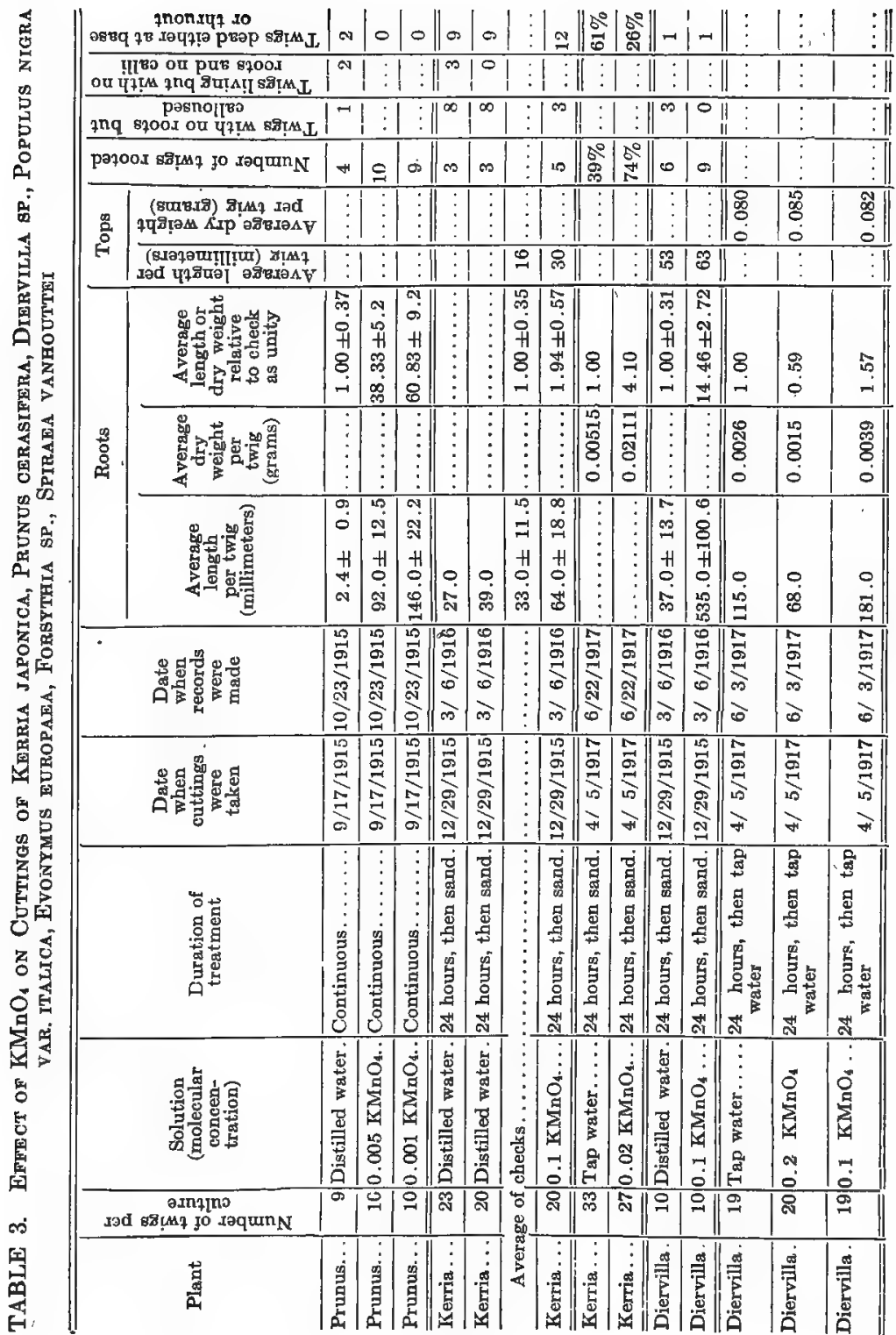




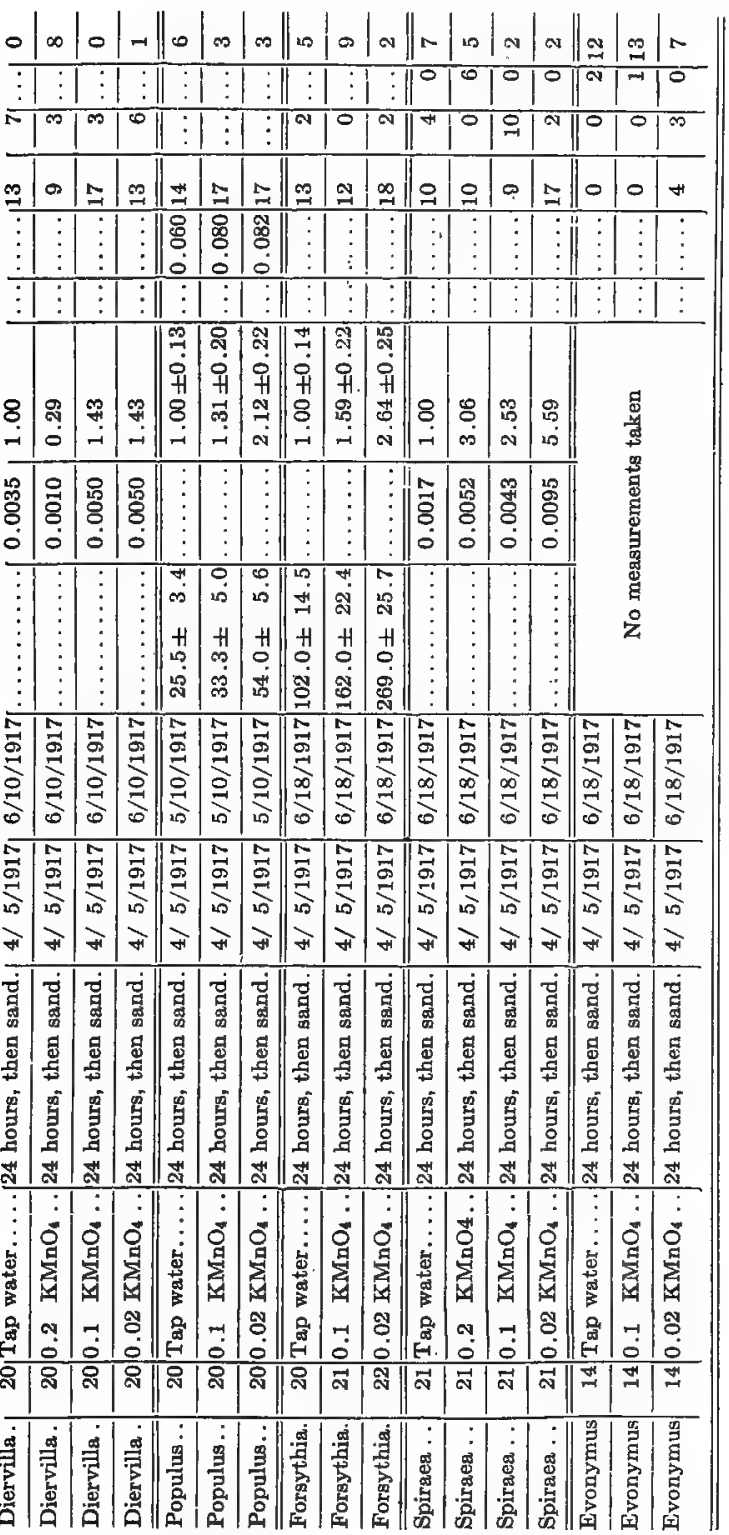




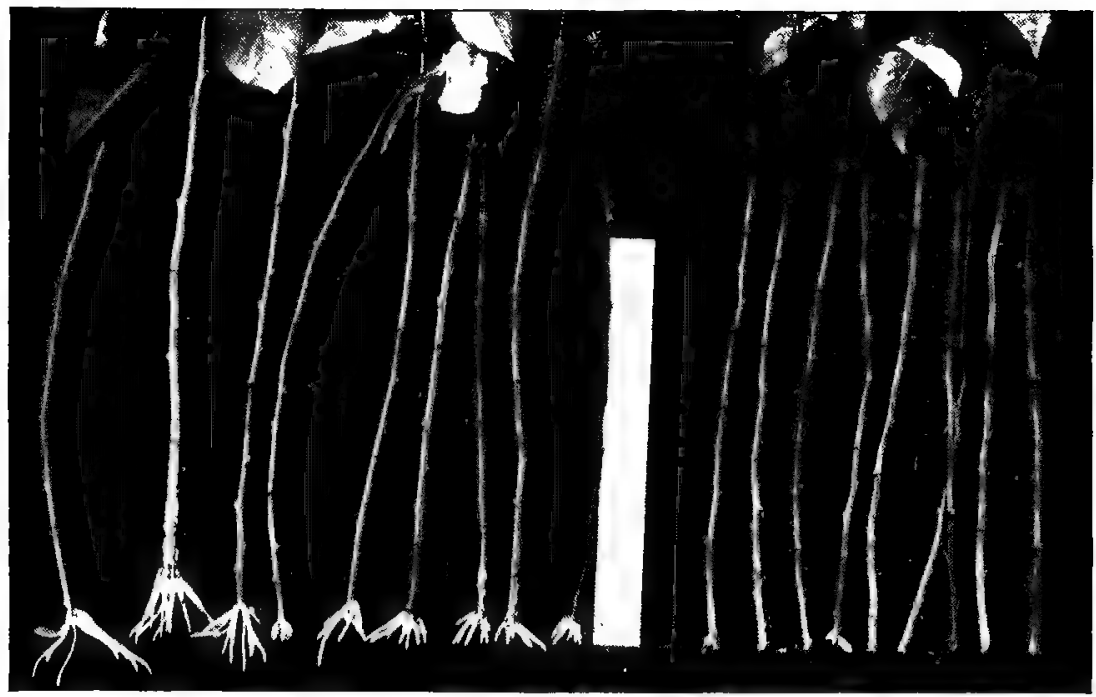

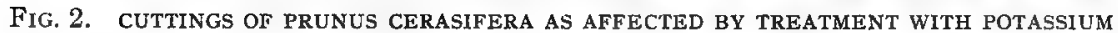
PERMANGANATE

The twigs at the left of the rule were kept continuously in $0.001 \mathrm{~mol} . \mathrm{KMnO}_{4}$; those at the right were kept continuously in water

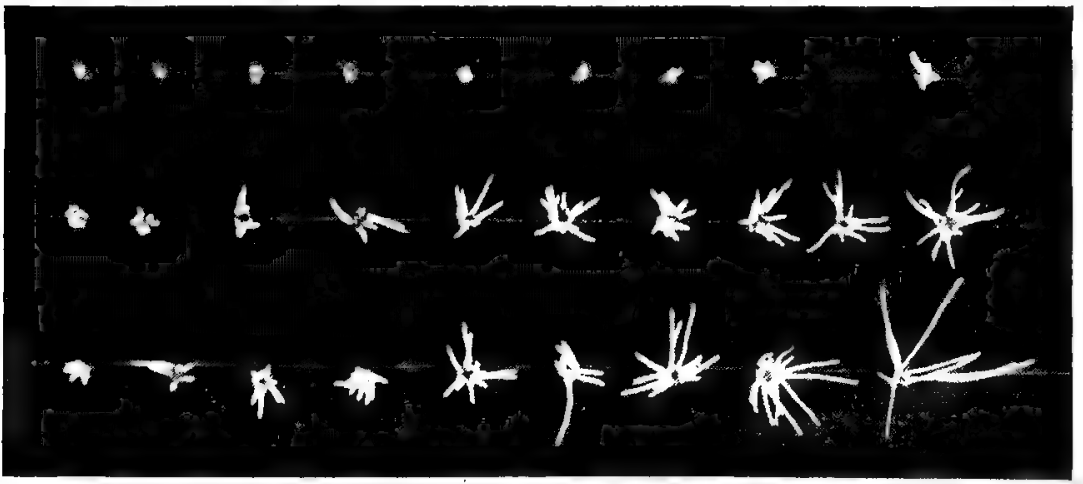

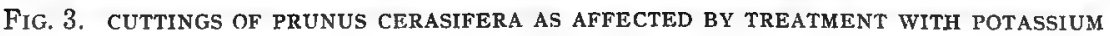
PERMANGANATE

Ton row: Check. Twigs from flasks containing water alone

Middle row: Twigs from flasks containing $0.005 \mathrm{~mol}$. KMnO,

Bottom row: Twige from flasks containing $0.001 \mathrm{~mol}$. KMnO, 
Ligustrum normally does. The treatment with potassium permanganate, however, largely nullified the unfavorable conditions, and both the root growth and the top development were very much increased (fig. 4).

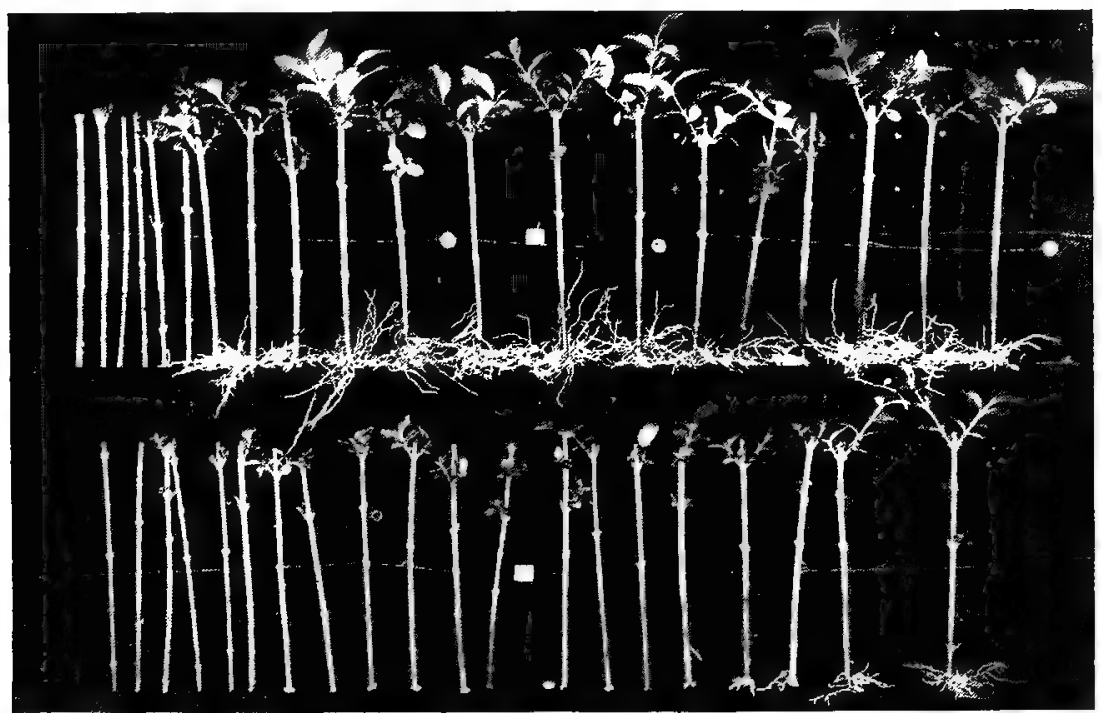

Fig. 4. EFFECT OF TREATMENT OF LiguSTRUM WITH POTASSIUM PERMANGanate UNDER RATHER ADVERSE CONDITIONS

Upper row: Cuttings treated for twenty-four hours with $0.1 \mathrm{~mol}$. $\mathrm{KMnO}_{4}$, then placed in sand

Lower row: Check. Cuttings left for twenty-four hours in tap water, then placed in sand

Table 4. Enfect of Treatment of Lugustrum with Potassium Permanganate under Rather AdVERSe Conditions

(Duration of experiment, March 16 to June 13, 1915. Twenty cuttings in each treatment)

\begin{tabular}{c|r|r|r|r}
\hline \multicolumn{1}{c}{ Treatment } & $\begin{array}{c}\text { Total dry } \\
\text { weight of } \\
\text { roots of } \\
20 \text { twigs } \\
\text { (grams) }\end{array}$ & $\begin{array}{c}\text { Dry weight } \\
\text { of roots } \\
\text { relative } \\
\text { to check } \\
\text { is unity }\end{array}$ & $\begin{array}{r}\text { Total dry } \\
\text { weight of } \\
\text { tops of } \\
20 \text { twigs } \\
\text { (grams) }\end{array}$ & $\begin{array}{r}\text { Dry weight } \\
\text { of tops } \\
\text { relative } \\
\text { to check } \\
\text { as unity }\end{array}$ \\
\hline $\begin{array}{r}\text { Check }-24 \text { hours in water, then } \\
\text { placed in sand............... }\end{array}$ & 0.14 & 1.00 & 1.47 & 1.00 \\
$\begin{array}{r}24 \text { hours in } 0.1 \text { mol. } \mathrm{KMnO}_{4}, \text { then } \\
\text { placed in sand.............. }\end{array}$ & 1.67 & 11.93 & 3.16 & 2.15 \\
\hline \hline
\end{tabular}




\section{REASONS OF STIMULATION}

\section{Possible effect on food supply}

In seeking the cause of the stimulating effect of potassium permanganate on root growth, it was thought possible that the treatment changed the food stored in the stem of the cutting so as to make it available for immediate use. In order to determine whether this was the case, cuttings were treated as in the preceding experiments for twenty-four hours and then placed in flasks of distilled water. Microchemical tests for sugar and starch were made at intervals of two days at first and of from seven to ten days later. In no case was there any loss of starch or production of sugar to be detected until rapid development of callus and roots started. When the callus was well formed, the starch in the immediate proximity of this tissue was disappearing, but no change was visible in the starch content at a distance of from three to four millimeters from the callus. In spite of the fact that the food remained unchanged until growth started, the treated twigs showed marked stimulation. When the roots were measured, those on the treated twigs averaged 5.32 times those of the checks - an increase of 432 per cent. It should be pointed out that the method of testing is not delicate enough to permit detection of slight changes in sugar or starch content.

It has occurred to the writer that the precipitation of manganese dioxide in the base of the stem may so clog the tissues as to check the loss of organic matter from the cut end. As a result of this check, more food might be available for root formation. This explanation has not been verified experimentally, but it would seem that it is of minor importance.

\section{Relation to rest period}

In many cases cuttings were taken in autumn, when they were still in the resting condition. It seemed possible, therefore, that the treatment might have served to bring either the entire twig or its basal part out of the rest period. If such were the case, the increased root growth might be merely due to the fact that the growth had started earlier in these twigs than in the checks, in which case there would be no true root stimulation.

Effect on rest period of twig as a whole.- In order to ascertain the effect of potassium permanganate on the rest period of the twig as a whole, Ligustrum cuttings were made on October 15, 1915, and were given continuous treatment as indicated in table 5 . As shown by the 


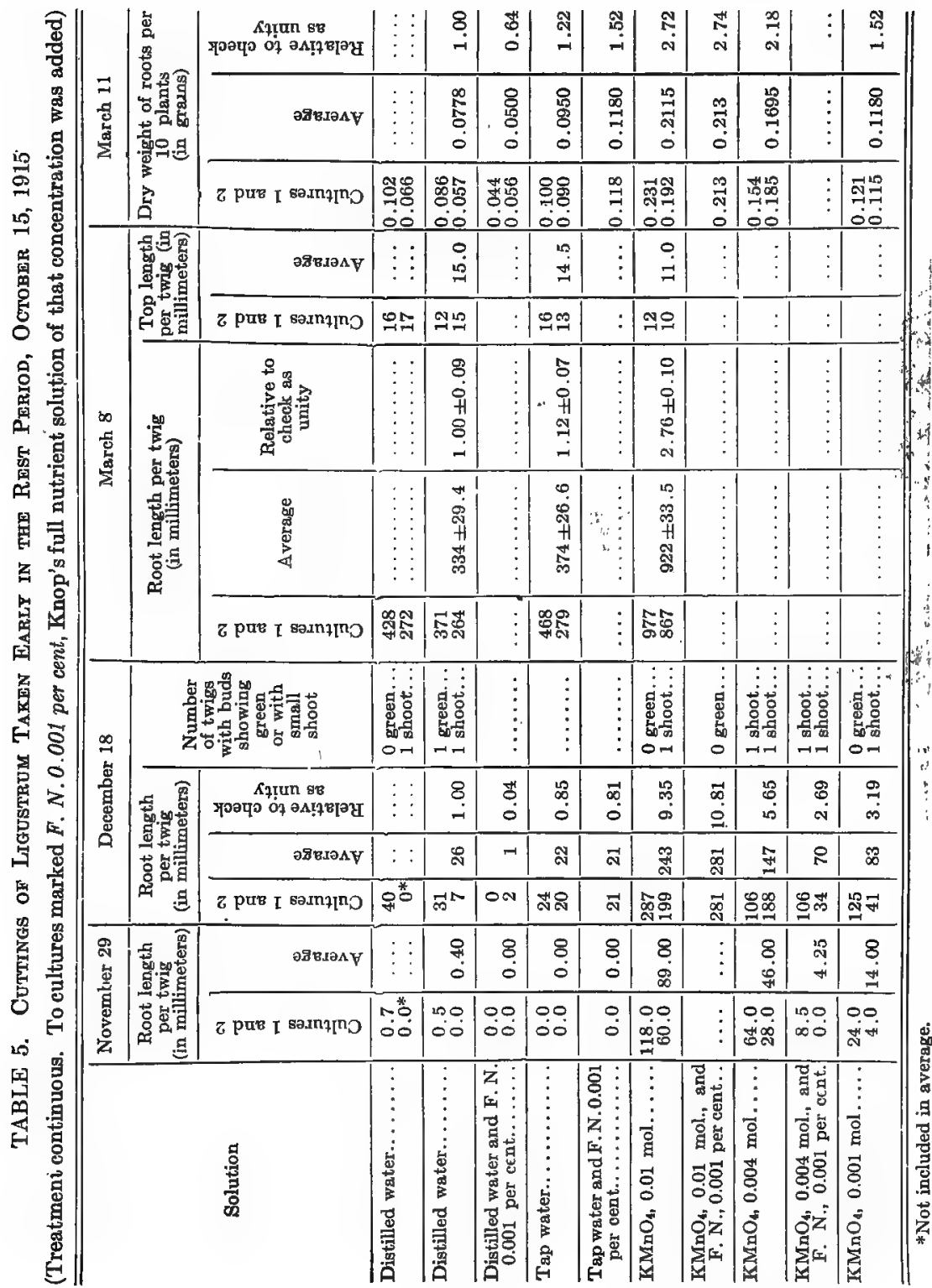


table and by figures 5 and 6 , the treatment with potassium permanganate markedly increased root growth but had little or no effect on the tops.

In the cultures with 0.01 and 0.001 molecular potassium permanganate, the roots were visible about ten days earlier than they appeared in the checks. This might seem to have been due to an effect on the rest period. If this were the case, however, the treatment had not affected the whole

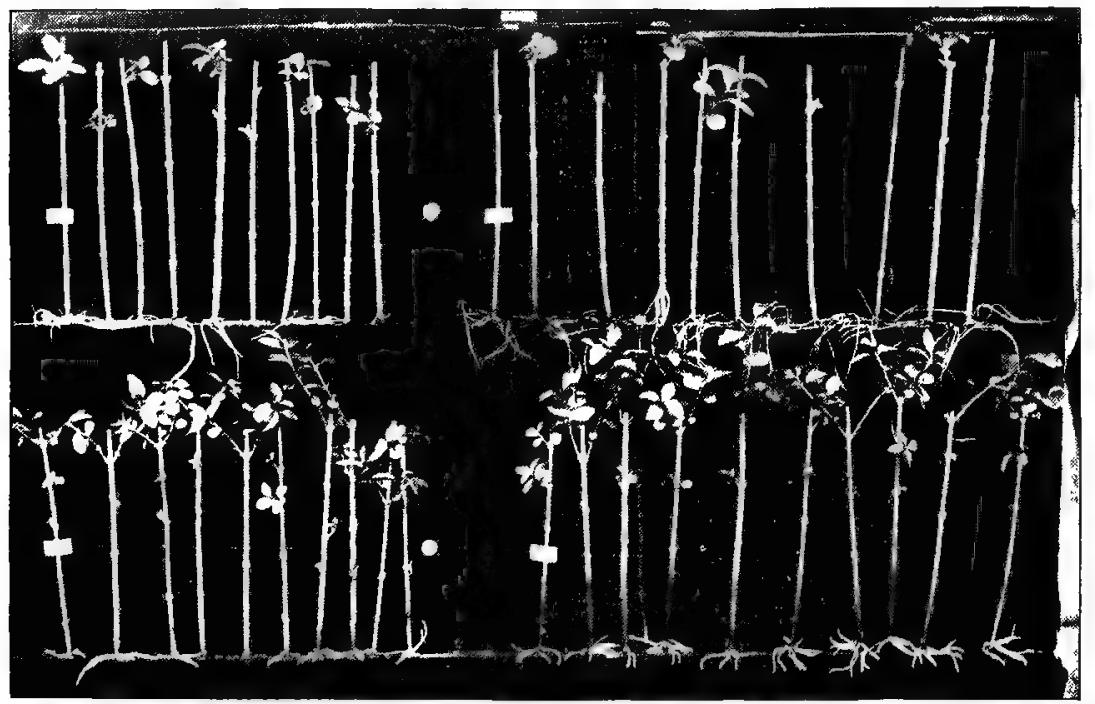

Fig. 5. Relation uf STIMUlation to Rest period

Upper row: Cuttings taken early in rest period, October 15, 1915. Twigs at left, check twigs, kept continuougly in distilled water until December 27, then placed in tap water. Twigs at right kept in $0.01 \mathrm{~mol}^{\mathrm{K}} \mathrm{KMnO}$ until December 27, then placed in tap water. The buds are just.starting to grow in both lots, showing approximately equal growth, while the root growth is very much greater in the treated twigs

Lower row: Cuttings taken at end of rest period, on December 8. Twigs at left, check twigs, Jeft for twenty-four hours in distilled water, then transferred to flasks containing distilled water. Twigs at right, treated for twenty-four hours in $0.1 \mathrm{~mol}$. $\mathrm{KMnO}_{4}$ then transferred to flasks containing distilled water. The shoots are well formed in both sets, while the roots have not grown so far as in the twigs shown above. Both roots and tops showed better growth in the treated twigs

twig, for, tho a few buds were started by December 18, these were equally developed on all the twigs whether treated or not. Altho these few. buds opened by December 18, most of the buds did not grow until about the first of March. The equal development of the buds indicates that the treatment has no effect on the resting condition of the whole twig.

Effect on rest period of basal part.- The only possibility remaining, so far as an effect on the rest period is concerned, is that the treatment 
may have started growth in the basal part, leaving the tops dormant, for in some instances the roots of the treated twigs started from three to ten days earlier than those of the checks. This difference in time of starting, however, is insufficient to account for the great difference in growth.

As shown by table 5 , the roots of the treated twigs when they had been visible less than two weeks (on November 29) showed growth more than three times that in the checks when the roots of the latter had been visible for at least three weeks (on December 18). Furthermore, as a result of the exposure on November 29, when the cultures were being photographed, the roots in the permanganate cultures were partly broken and dried, so that when measured the second time many of the roots first formed were completely rotted or the ends had died back and new branches were starting. The checks were not injured for no roots had started at that time. In spite of this injury to the treated twigs, the growth was much better in these than in the checks and continued better as long as the cultures were kept. This great difference in root length at the time of the final measurements, which were taken more than twelve weeks after growth had commenced, cannot be explained on the ground that the treated twigs had a start of ten days.

Stimulation of root growth in twigs that have passed the rest period.- The following experiments furnish additional proof that the stimulation of root growth by potassium permanganate has nothing to do with the rest period. Cuttings of Ligustrum were taken on December 8, 1915. The bushes from which they were taken had been twice subjected to several days of freezing weather, and, as is brought out later, these twigs had passed out of the resting condition. One hundred and fifty twigs were treated for twenty-four hours in water, and the same number in 0.1 molecular potassium permanganate. After being rinsed, duplicate lots of ten twigs from each treatment were placed in distilled water in a cool room at a temperature of from $5^{\circ}$ to $10^{\circ} \mathrm{C}$., thirty twigs of each treatment were placed in sand in a somewhat warmer, shaded greenhouse at from $10^{\circ}$ to $15^{\circ} \mathrm{C}$., and one hundred twigs of each treatment were placed in sand in a still warmer, unshaded greenhouse at from $18^{\circ}$ to $22^{\circ} \mathrm{C}$.

The buds of the twigs in the warmest house started almost immediately after the cuttings were set out. They were not in the resting condition, and the treated and the untreated twigs started equally; but by the 
last of January, when this lot was taken up, the twigs treated with potassium permanganate showed accelerated top growth. No actual measurements were taken of this lot, but the root growth was fully twice that of the checks. The buds of the lot placed in sand in the shaded house opened soon after these. There was no apparent difference in time of starting between the treated and the untreated twigs, but at the end of about ten days those treated with potassium permanganate clearly showed increased top growth. Similar results were obtained with the cuttings placed in water in the cool room.

Results obtained from experiments conducted in the spring of 1917 were very similar to those just described. On cuttings treated either continuously or for a limited time with potassium permanganate, an increased growth of roots ranging from 2.17 to 1193 times that in the checks was produced. Results following the placing of the cuttings in sand after treatment for twenty-four hours in 0.1 molecular potassium permanganate are shown in figure 4 (page 87).

The buds on all the twigs in these experiments opened very soon after the twigs were set out, and even before the roots started. For this reason the stimulation cannot be explained as due to an effect which may bring the basal part of the twig out of the resting condition and leave the tops dormant. These twigs apparently had completely passed the rest period, and therefore any stimulation obtained cannot have been due to an effect on the rest period. Furthermore, it has been shown by Howard (1915 b), and by other investigators, that, so far as the rest period is concerned, treatments which will exert a stimulating effect if applied during the rest period will have no effect, or may even produce a retarding effect, if applied at or near the end of that period.

True rest shown only by buds of woody cuttings. - The effect of stimulation of root growth is evidently independent of the rest period, as already stated. So likewise are callus formation and root development, which proceed in untreated twigs whose buds are dormant. The buds of cuttings taken on October 15 (fig. 5) did not start general growth until about March 1, approximately four months after the cuttings were taken, while the buds of twigs taken on December 8 started almost immediately. Those taken on December 8 were well started by December 22, only two weeks after the cuttings were made and more than two months earlier than those taken on October 15 . The roots in the untreated twigs, however, 
developed at approximately the same rate whether the twigs were taken before or after the end of the rest period. In both cases the roots were about equally developed forty-five days after the cuttings were made. Very sim lar results were obtained with cuttings of Prunus cerasifera, Cornus stolonifera Michx., and Evonymus europaea, and with regard to callus formation in Pyrus malus.

Cuttings of Evonymus taken in the latter part of September had a strong root system developed by March 1, yet the buds did not break until May 1; while the buds on cuttings taken from the same bush on December 29 started growth within ten days, but as no root system was developed a large number of the twigs withered. Root and callus formation in cuttings, therefore, appear to be independent of the rest period, as stated above. There is a possibility that the wound shock at the cut end brings that part out of the rest period; Howard (1915 b) and other investigators have found that such a stimulus may shorten the rest period. But in some cases the roots develop at some distance from this wounded tissue, and therefore this explanation is insufficient. The cut of course exposes the adjacent tissue to better aeration, resulting in a greater oxygen supply as well as a more rapid loss of carbon dioxide, which might serve to start growth in the dormant cambium. When the twig is immersed in water any inhibiting substances may be washed. out of the tissues or the ready access of oxygen may oxidize them. Such an explanation is not entirely satisfactory, however, for if the twig is kept in a moist chamber, not only will both cut ends develop a callus but also cork cells will be formed at the lenticels, indicating cellular activity in regions far from the wounded part; yet in no cases do the buds develop, even when submerged in water or when situated very close to the cut end.

Simon (1906) has shown that root and callus formation proceed when the buds are in a resting state. Howard, in his work on shortening the rest period of cut twigs, makes no mention of any effect on their rooting ability. In a report on experiments with several species of potted woody plants (Howard, $1915 \mathrm{~b}$ ), he states that treatments which stimulated the tops had no effect on root growth. He does not say, however, how he determined this, and he gives no data.

Possibility that a treatment affecting the rest period may at the same time affect root growth - On the other hand, the fact that the stimulation obtained was independent of an effect on the rest period is no proof 
that treatments which would affect the rest period might not also have an effect on root growth. In order to test this point, Ligustrum twigs were taken on November 13 and tied in bundles of twenty twigs each. These bundles were suspended in water for two hours, at the depths and temperatures indicated in table 6 , and were then placed in sand in the cutting bench. It is to be noted that at each temperature the top

Table 6. Effyct of Warm-Bath Treatment on Dormancy and Root Growth (Treatment lasiing two hours; (a), from $2 \frac{1}{2}$ to 3 centimeters at base immersed; (c), entire twig immersed. Twenty twigs per culture)

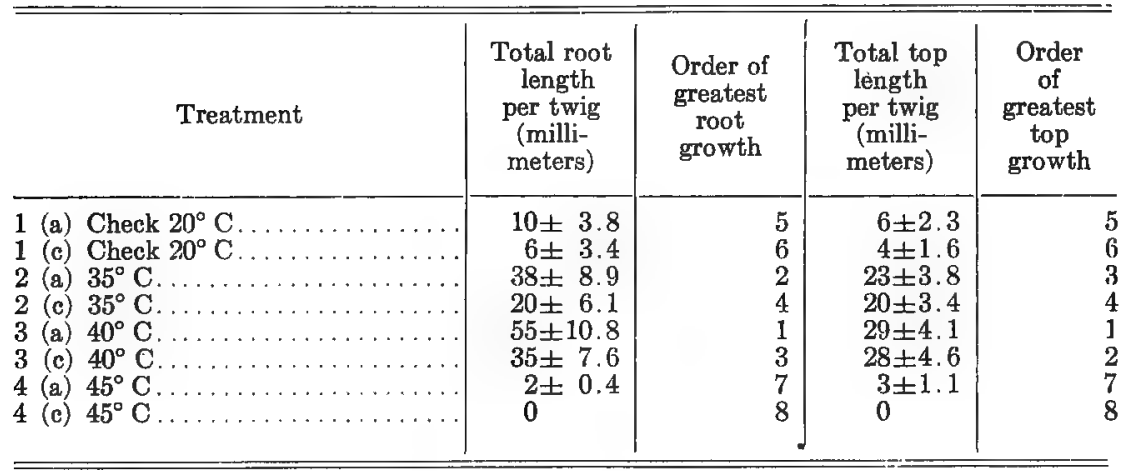

growth, as well as the root growth, was better in those twigs of which the bases only were immersed. The order of greatest growth of roots follows almost identically that of the greatest growth of tops. The results indicate that some treatments which start or increase growth in the entire twig may correspondingly increase root growth. It does not seem possible, however, to start growth at the base of the twig by the warm-bath treatment and leave the tops dormant.

Very similar results as to root growth were obtained with twigs taken on September 10 and treated in the same manner. No notes as to the effect on top growth, however, were made at that time.

Effect of treatment on correlation between tops and roots

Another possibility that has suggested itself is that the treatment may have brought about a change in correlation between tops and roots, an effect that might be due to a divergence of food movement from tops 
to roots. The table's already presented show that this is not the case with the permanganate treatment. In the experiment recorded in table 5 (page 89) there is practically no difference between top growth in the treated twigs and in the checks, and yet there is a very great difference in root development (fig. 5, page 90). The results obtained in the warm-bath treatment (table 6), and in four cases in which the twigs were treated with potassium permanganate after the rest period, showed that both top and root growth were better in the treated twigs than in the checks (fig. 5). This proves clearly that in these cases the roots did not develop at the expense of the tops. It is to be noted here that if the treatment is applied early in the rest period it generally has little or no effect on top growth even for some time after the buds start; while if it is applied after the rest period, tho the buds may start equally the shoots of the treated twigs usually soon surpass those of the checks in development, so that the length and the dry weight of both the tops and the roots exceed those of the checks. With the stronger concentrations, however, a point is apparently reached where there is still stimulation of root growth but at the same time a distinct retardation of top growth. This is well illustrated in table 10 (pages 106-7), which shows that the stronger solutions of both potassium permanganate $\left(\mathrm{KMnO}_{4}\right)$ and ferric chloride $\left(\mathrm{FeCl}_{3}\right)$ increased root growth but clearly decreased top growth. Weaker solutions stimulated both tops and roots. Accompanying the increased growth of tops and roots there is at first a lessened dry weight of the stem. After continued growth, however, the stems become heavier, probably due to the increased photosynthetic activity of the larger tops.

On the other hand, Faivre (1871) has shown that in some cases the tops may develop at the expense of the roots. He found that after the buds had formed shoots there was insufficient food left in the stem for root formation. The rooting process seems, as a rule, to be slower than growth of tops, so that if the tops are in a condition to grow they will develop faster than the roots and deplete the food supply, or else, as sufficient water for the increased transpiration is not supplied, the shoots will die, causing the twigs to wither at the same time. As stated earlier, cuttings of various species were taken in late autumn before the end of the rest period and were set out in the greenhouse benches. The tops of most of these remained dormant until March or later, while the roots or the callus in the case of the twigs of Pyrus - proceeded to develop 
vigorously. The buds on the twigs of the same forms taken in January started to grow within two weeks after the cuttings were set out. In the majority of such cases the young shoots, as well as the cutting itself, soon withered and died from lack of water. With Ligustrum, however, root development was so rapid that the majority of the twigs remained alive. Whether this is a matter of food distribution or merely a water relation is not clearly shown by these experiments.

\section{Effect of treatment on respiratory activity}

The explanations of stimulation of root growth which have thus far been discussed have been shown to be insufficient to fully account for the increased growth resulting when cuttings are treated with potassium permanganate. A more probable explanation appears to be that the manganese increases the rate of respiration in the treated twigs or causes more complete oxidation, thereby preventing the accumulation of inhibiting or toxic products of catabolism.

It has long been recognized that good aeration is essential for root growth either of seedlings or of cuttings, and especially of the latter. De Saussure (1804), early in the nineteenth century, pointed out the fact that oxygen is necessary for root growth of seedlings. He grew chestnut seedlings in flasks containing air, nitrogen, hydrogen, and carbon dioxide, respectively. The carbon dioxide was distinctly injurious to the roots, while the other gases did not allow for growth and the roots soon died. It is commonly understood that one of the chief reasons for the practice of soil drainage is to provide better aeration. Stoklasa and Ernest (1908) have shown that poor aeration of root systems leads to the formation of compounds such as acetic and formic acids within the roots, which may result in their death.

Harris (1914) and a number of other investigators have shown that the growth of roots and the depth to which they penetrate are closely correlated with the water content of the soil and the height of the water table. Harris, as well as several other investigators, states that this is probably due to the fact that a high water content excludes oxygen and the lack of oxygen limits root development.

There is apparently an even greater need for good aeration in soils in which cuttings are placed, than exists for seedlings. This fact has been 
recognized for some time. Sorauer (1895) lays strong emphasis on the need of aeration, especially for herbaceous cuttings.

Küster (1903) states that cuttings always callus more readily in a moist atmosphere than in water, tho he considers transpiration, as well as oxygen supply, a determining factor.

Klebs (1903) found that cuttings of Salix pentandra develop roots only at the cut end of the twig, not thruout its length as do cuttings of Salix alba vitellina pendula (Spath.); however, if the cork layer is removed at a point some distance from the cut end, roots will develop in or near this region. He explains this on the theory that water is the determining factor. He suggests that on removal of the impervious cork layer, water enters the twig, and the roots then develop. He does not realize, apparently, that when the twig is immersed the tissues must be practically saturated - certainly of greater water content than those of the basal end when the cutting is suspended in moist air, yet under the latter condition roots will develop freely. The more probable explanation is that the removal of the cork allows for better aeration, thus increasing the oxygen supply at that point as well as supplying an outlet for the carbon dioxide produced in respiration. The work of Appleman (1916) is suggestive in this connection. He found that tubers of Solanum tuberosum were caused to sprout when the skins were removed. The results he explains as due to increased permeability to oxygen.

It is very generally known that when potassium permanganate comes in contact with organic matter, manganese dioxide is precipitated and oxygen is liberated. Some of the most recent work on this line is that of Bunzell and Hasselbring (1917), who found that various organic compounds - glucose, alcohol, and others - will decompose potassium permanganate with the formation of manganese dioxide and in some cases a straw-colored solution containing manganese and giving strong oxidase reactions.

The cuttings treated with potassium permanganate were very much blackened by this precipitate of oxide of manganese, which clings firmly to the surface of the twig. Sections of the twig showed the oxide deposited in the xylem cells for a distance of from one to four millimeters from the cut end. They showed also a slight penetration into the cortex cells thruout the length of the immersed part. 
Most manganese compounds are active oxygen carriers or are easily changed to such. This is especially true of potassium permanganate and manganese dioxide. The latter, which is precipitated on and in the twigs as just described, will almost instantly blue guaiacum or redden aloin and decompose hydrogen peroxide. It can therefore act as an oxidase, a peroxidase, or a catalase. Bunzell and Hasselbring (1917), as stated above, have found that various organic compounds - glycerin, tyrosine, peptone, glucose, and others - will decompose potassium permanganate, producing a precipitate of manganese dioxide and also a solution containing some manganese which will give oxidase, peroxidase, and catalase reactions. Whatever stimulation was obtained in these experiments was probably due chiefly to this oxide adhering to the walls or precipitated within the cells. It is probable that it was not due to the permanganate itself, as this seemed very toxic to the roots of seedlings or of herbaceous cuttings. In such cases the roots were formed when the purple color was still present in solution. With the woody cuttings, however, all the purple color had disappeared before the roots started, and the solution contained only the dark brown or black oxides of manganese. In continuous treatments the solution may have contained also some manganese available for oxidizing, as found by Bunzell and Hasselbring. In those cases in which the treatment lasted for only a limited time, the twigs were thoroly rinsed before being placed in the final medium, and therefore no permanganate was carried over.

It has been shown by several investigators that manganese is closely associated with oxidation reactions occurring in plants. Bertrand (1897) found it to be an important constituent of the oxidizing enzyme laccase. When a sample of laccase was not very active, its activity was increased by adding a small quantity of manganese sulfate. Schreiner, Sullivan, and Reid (1910) found that the presence of manganese markedly increased oxidation by soils and by plant roots. This occurs, however, only in neutral or alkaline soils (Skinner and Reid, 1916). McHargue (1914) found manganese to be especially abundant in the seed coats of various seeds next to the cotyledons, and suggested that it played an important rôle in respiratory activities during germination. He found that the oxidase activity of different parts of seeds, tubers, roots, and stems varied directly with the manganese content. Kastle (1910:122-131) cites sev- 
eral instances in which investigators have found that manganese is important in the action of a number of oxidases.

It would therefore seem reasonable to explain the marked stimulation obtained with treatment by potassium permanganate as due to the effect of the manganese dioxide, deposited on and in the twig, on the respiratory activity of the cutting, either by directly hastening respiration or by causing more complete oxidation and thereby preventing the accumulation of partially oxidized, toxic, or inhibiting products of catabolism. Such an effect occurring within the tissues would be very similar to that which may occur in the external medium in the presence of microorganisms, as discussed later.

The lack of stimulation with certain forms, notably Salix, may be explained on the theory that the oxygen supply does not become a limiting factor with such forms, and therefore, as the effect of the manganese is merely to increase oxidation, no increased growth is to be expected. The fact that Cannon and Free (1917) found Salix to be peculiar in that its roots were uninjured by lack of oxygen or excess of carbon dioxide, lends weight to this explanation.

\section{Effect of treatment on growth of microorganisms}

The increased growth of roots when cuttings are treated with potassium permanganate cannot be due to any direct effect in keeping the solution sterile and free from microorganisms, altho in experiments with Pyrus malus, Evonymus europaea, and Forsythia sp., and also in other experiments not here reported, the cuttings treated with permanganate remained alive and vigorous for a much longer period without root formation than did the checks. Pyrus twigs remained in good condition for from six to ten months, while most of the check twigs were rotting after from one to three months. On close examination the treated twigs appeared to be heavily coated with a slimy growth of fungi and bacteria, yet they werealive and healthy. The cultures were certainly not sterile; in fact, in one experiment several of the cultures that showed the greatest root growth apparently had a growth of microorganisms even greater than that in the cultures not treated with permanganate. As shown in table 7, the twigs in the culture with 0.004 molecular cane sugar were slimy to a slight extent on December 18, and those in the culture with 0.004 molecular cane sugar plus 0.004 molecular potassium permanganate were 


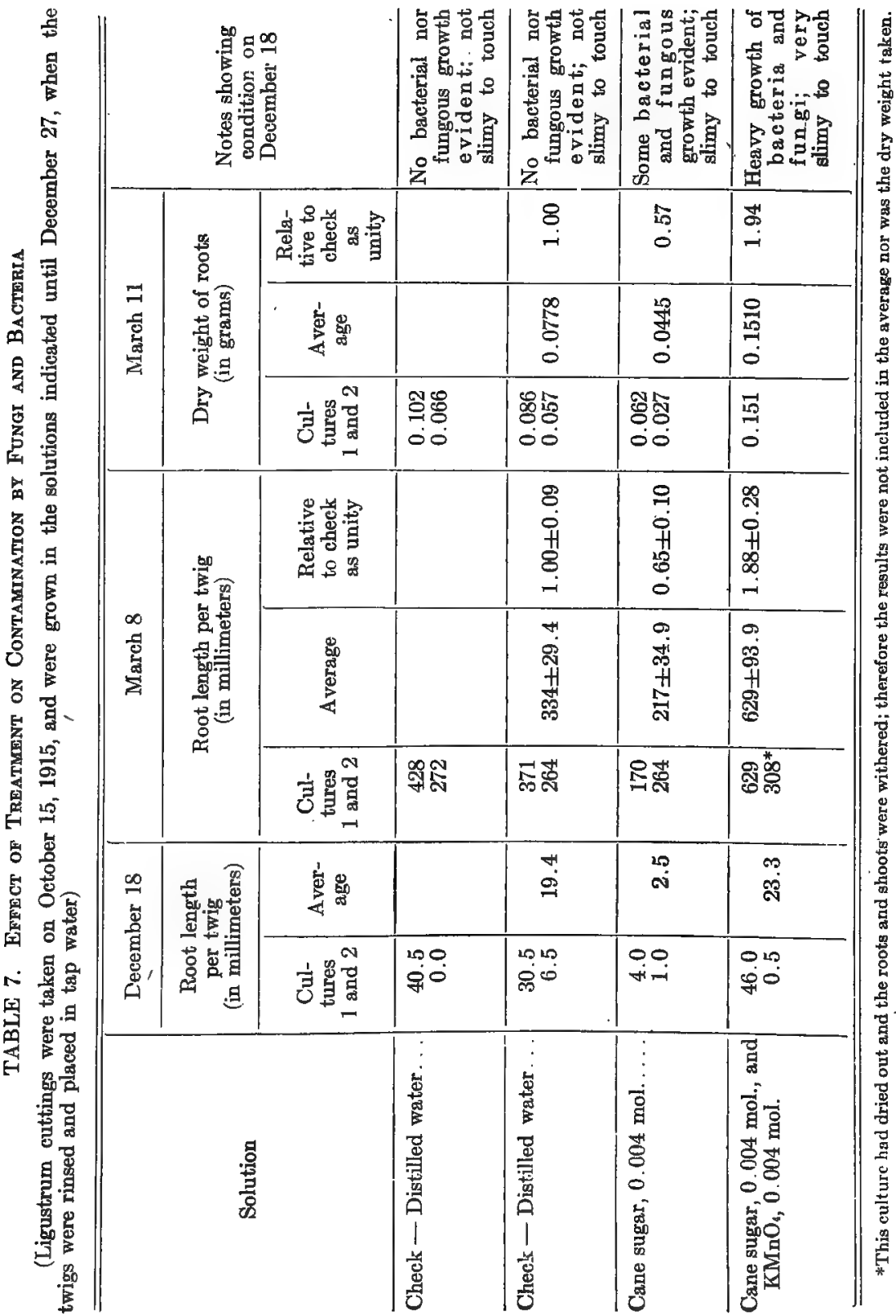




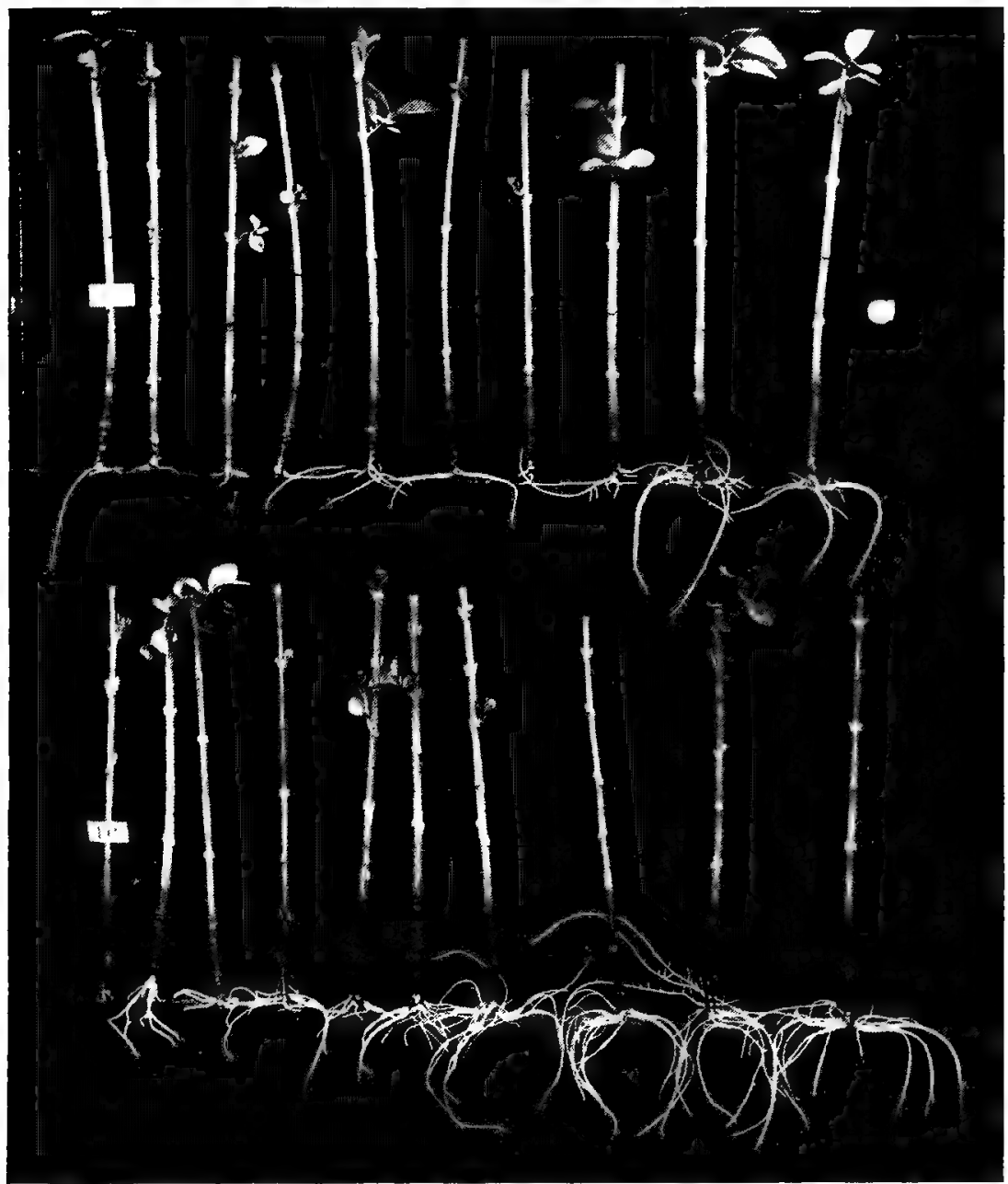

Fig. 6. EFFECT OF TREatMent with POTASSIUM PERManganate ON ROOT GROWTH AS CORRELATED WITH ITS EFFECT ON GROWTH OF MICROORGANISMS

Upper row: Cuttings grown in $0.004 \mathrm{~mol}$. cane sugar

Lower row: Cuttings grown in $0.004 \mathrm{~mol}$. cane sugar with $0.004 \mathrm{~mol}$. $\mathrm{KMnO}$, 
much more slimy, with a mat of growth around the stem; yet the roots of the latter, were much better developed. When measured later, on March 11, the twigs treated with permanganate and sugar had a root, growth 3.39 times that of the twigs treated with sugar alone (fig. 6), which were noticeably less slimy; and the former had a growth 1.94 times that of the plants not supplied with sugar, the stems of which were not slimy to the touch. It would seem, then, that the growth of microorganisms does not of itself injure the cuttings, but that for some reason they become weakened and die, following which fungous growth sets in, attacking the dead twigs.

It is very probable that the presence of soluble organic material allows for a much increased growth of microorganisms, which would result in an increase of carbon dioxide and various toxic compounds and a decrease of oxygen. This increase of carbon dioxide has been found to occur in soils where green crops are plowed under or in ground that has been heavily manured (Boussingault and Léwy, 1852, and Lau, 1906). Kidd (1914) found that the carbon-dioxide content of the soil was very much increased when clipped grass was buried in a pit beneath it; after seven months the soil air of such a pit contained 8 per cent of carbon dioxide. As stated earlier, De Saussure (1804) found that an increased carbondioxide content retarded root growth in seedlings. Boehm (1874), Chapin (1902), and Cannon and Free (1917) also have reported retardation of root growth in the presence of carbon dioxide.

It would seem very probable that the increased carbon-dioxide content resulting from the action of microorganisms on the organic material in the medium is injurious to cuttings. Kidd (1914) has shown that carbon dioxide has a retarding effect on respiration, and that this effect is enhanced by a decrease in oxygen content. Microorganisms growing in a medium containing organic matter not only increase the carbon-dioxide content but also decrease the percentage of oxygen. This decreased oxygen supply, coupled with an increased carbon-dioxide content, would tend to retard respiration or to retard the further oxidation of toxic products, thereby causing the death of the twigs, which later might be attacked by saprophytic forms or might be so altered as to be easily attacked by semiparasites.

Furthermore, Chapin (1902) observed that the roots of plants are more resistant to a high carbon-dioxide content than are the tops. This 
may partially explain the fact that parts of tops, such as cuttings without roots, are more quickly injured in a soil with a high organic and carbondioxide content or a low oxygen content than are rooted cuttings or seedlings. It is certainly true that cuttings are less tolerant of poor aeration. Kidd (1914) found that a rise in temperature lessened the inhibiting effect of carbon dioxide. This might partially explain the beneficial effect of bottom heat, which is discussed later.

In a few preliminary experiments with cuttings inclosed in chambers with increased oxygen content and in chambers with increased carbondioxide content, respectively, the cuttings in the increased carbon-dioxide content were distinctly injured, while those in the increased oxygen content remained healthy much longer than did cuttings in normal inclosed air. In none of these preliminary experiments did any of the Ligustrum cuttings remain healthy long enough to form roots. Some very suggestive results, however, were obtained by placing twigs under a suction pump, reducing the pressure by suction, and then replacing the air with carbon dioxide or oxygen. Results from such treatment are illustrated in table 8:

Table 8. Effect on Root Growth when the Gas in Twigs of Ligustrum is Replaced with Oxygen or Carbon Dioxide

(Cuttings taken on March 29, measured on June 2, 1917. Ten twigs to the culture)

\begin{tabular}{|c|c|c|c|c|c|}
\hline \multirow[b]{2}{*}{ Treatment } & \multirow{2}{*}{$\begin{array}{l}\text { Num- } \\
\text { ber of } \\
\text { cultures } \\
\text { used }\end{array}$} & \multicolumn{2}{|c|}{ Roots } & \multicolumn{2}{|c|}{ Tops } \\
\hline & & $\begin{array}{c}\text { Average } \\
\text { total length } \\
\text { per twig } \\
\text { (millimeters) }\end{array}$ & $\begin{array}{l}\text { Relative } \\
\text { to check } \\
\text { as unity }\end{array}$ & $\begin{array}{l}\text { Average } \\
\text { total length } \\
\text { per twig } \\
\text { (millimeters) }\end{array}$ & $\begin{array}{l}\text { Relative } \\
\text { to check } \\
\text { as unity }\end{array}$ \\
\hline $\begin{array}{l}\text { Check, untreated. } \\
\text { Oxygen ....... } \\
\text { Carbon dioxide* }\end{array}$ & $\begin{array}{l}2 \\
4 \\
2\end{array}$ & $\begin{array}{r}77.0 \pm 18.4 \\
76.6 \pm 15.5 \\
1.5 \pm 0.8\end{array}$ & $\begin{array}{l}1.00 \pm 0.24 \\
0.99 \pm 0.20 \\
0.02 \pm 0.01\end{array}$ & $\begin{array}{r}101.6 \pm 3.7 \\
105.6 \pm 2.8 \\
76.8 \pm 4.7\end{array}$ & $\begin{array}{l}1.00 \pm 0.04 \\
1.04 \pm 0.03 \\
0.75 \pm 0.05\end{array}$ \\
\hline
\end{tabular}

* Only one twig in each culture was rooted; the others had very weak calluses or none at all.

The twigs were placed under suction for twenty minutes and then allowed to stand in the gas at atmospheric pressure for sixteen hours. They were then removed and placed in flasks of tap water. The single injection of carbon-dioxide gas distinctly retarded both root and top development. 
The injurious effects resulting from the presence of organic matter may not be limited to those directly correlated with increased carbondioxide or decreased oxygen content. It is very probable that there are certain toxic, partially oxidized substances formed which are directly injurious. In fact, evidences of fermentation and putrefaction were shown by tests for alcohol and by the odor of the solution. Aside from the direct effect of increased carbon-dioxide and decreased oxygen on the respiration of the cuttings, the same condition would tend to increase the production of these partially oxidized toxic substances in the medium. Stimulation by manganese may not be directly due to its effect on respiration of the cutting, as discussed in the preceding pages, but it may be indirectly due to the reduction of toxicity as a result of more complete oxidation carried on either by the cutting or by the microorganisms, or possibly in the solution independent of either. Loew (Loew and Sawa, 1902-03) has suggested a similar rôle for manganese - that it serves to carry on oxidation to completion, thereby preventing the accumulation of toxic, partially oxidized by-products.

COMPARISON OF THE EFFECT OF POTASSIUM PERMANGANATE WITH THAT OF OTHER MANGANESE COMPOUNDS, AND ALSO WITH THAT OF IRON, OF ALUMINIUM, OF BORON, AND OF PHOSPHORUS

Since manganese dioxide seemed to be one of the active principles in stimulating root growth in the experiments thus far cited, experiments were made to determine whether this compound added directly to the medium would have a similar effect. At the same time other compounds were used which, according to the literature available, had under certain conditions stimulated root growth in seedlings, or which, as in the case of iron, were supposed to have some connection with oxidizing enzymes.

\section{Experiments with herbaceous cuttings}

The first experiment was made with tomato cuttings, since these root very quickly and would give an idea as to the approximate concentrations to be used. The stems were not of uniform size but care was taken to distribute them equally. Duplicate cultures of five cuttings each were set up. The roots were measured six days after the cuttings were started, with the results shown in table 9 : 
Table 9. Comparison of the Efhect of Various Stimulants on the Root Growth of Tomato Curtings

(Duration of experiment, July 31 to August 6. Five cuttings to the culture)

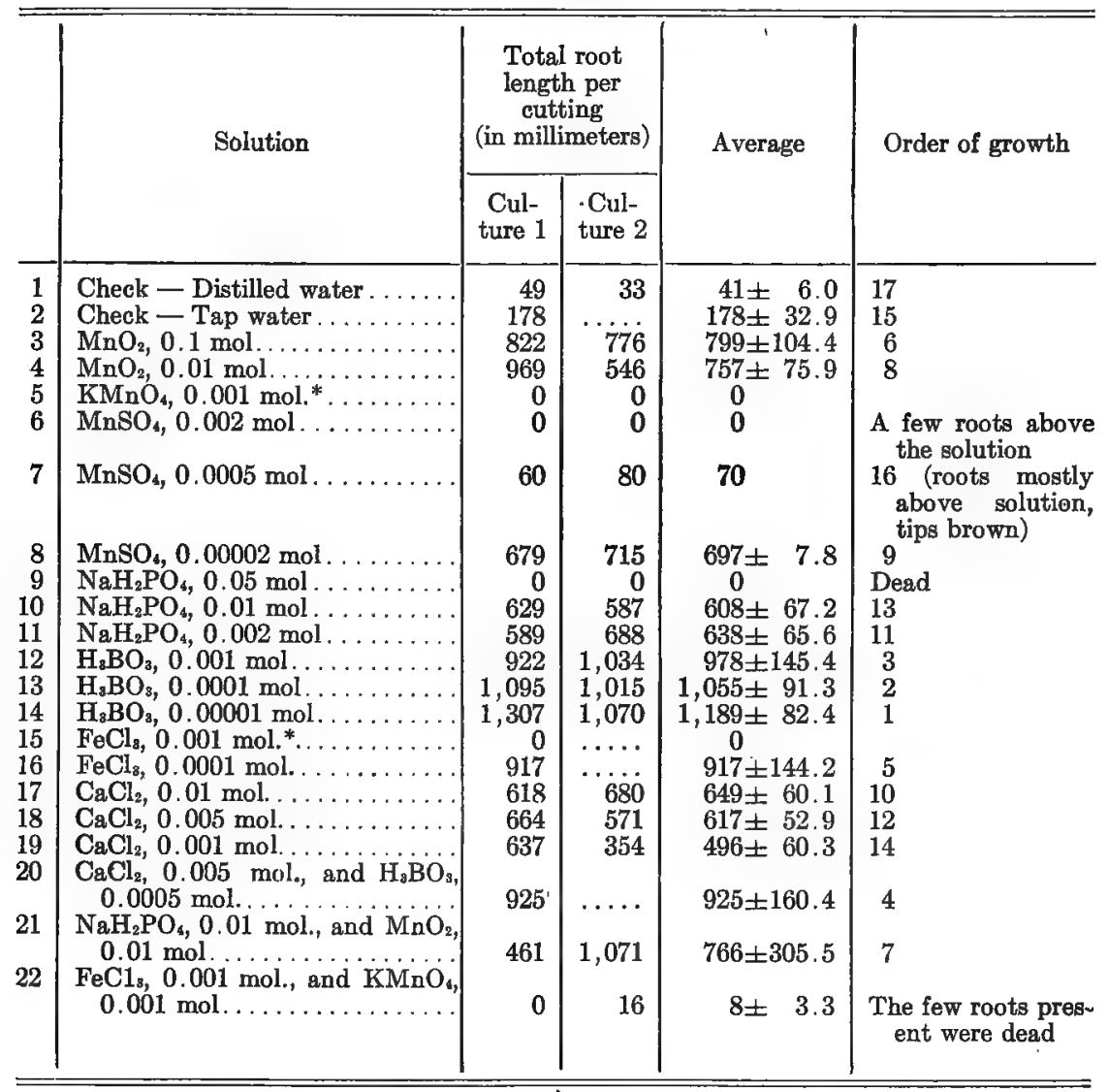

* All stronger solutions showed no growth.

The results were more consistent than was to have been expected from the small number of stems used and their lack of perfect uniformity. The four treatments showing the best growth all contained boric acid. Ferric chloride stood fifth, while the three containing manganese dioxide stood next in order followed by manganese sulfate in its weakest solution. 


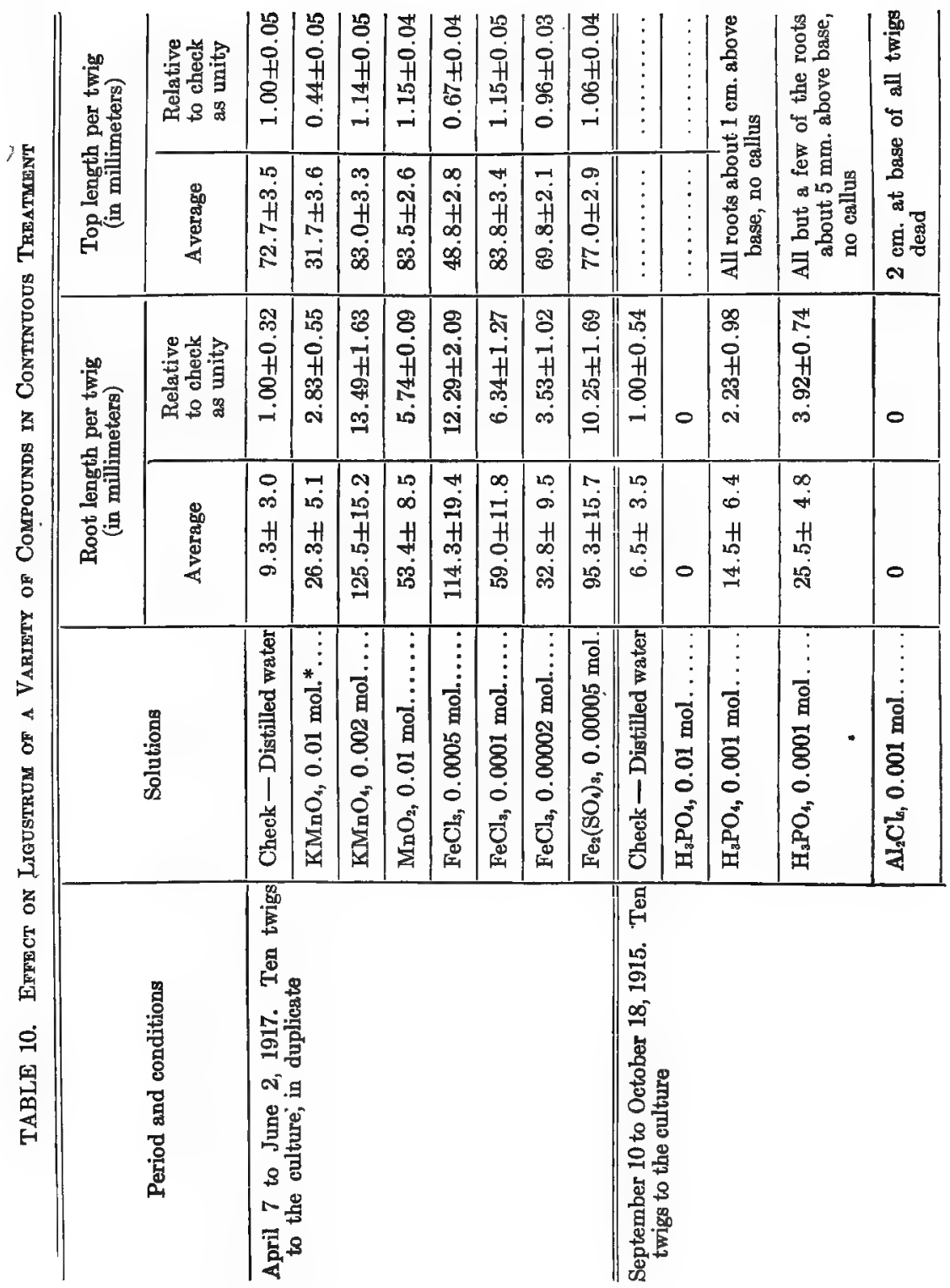




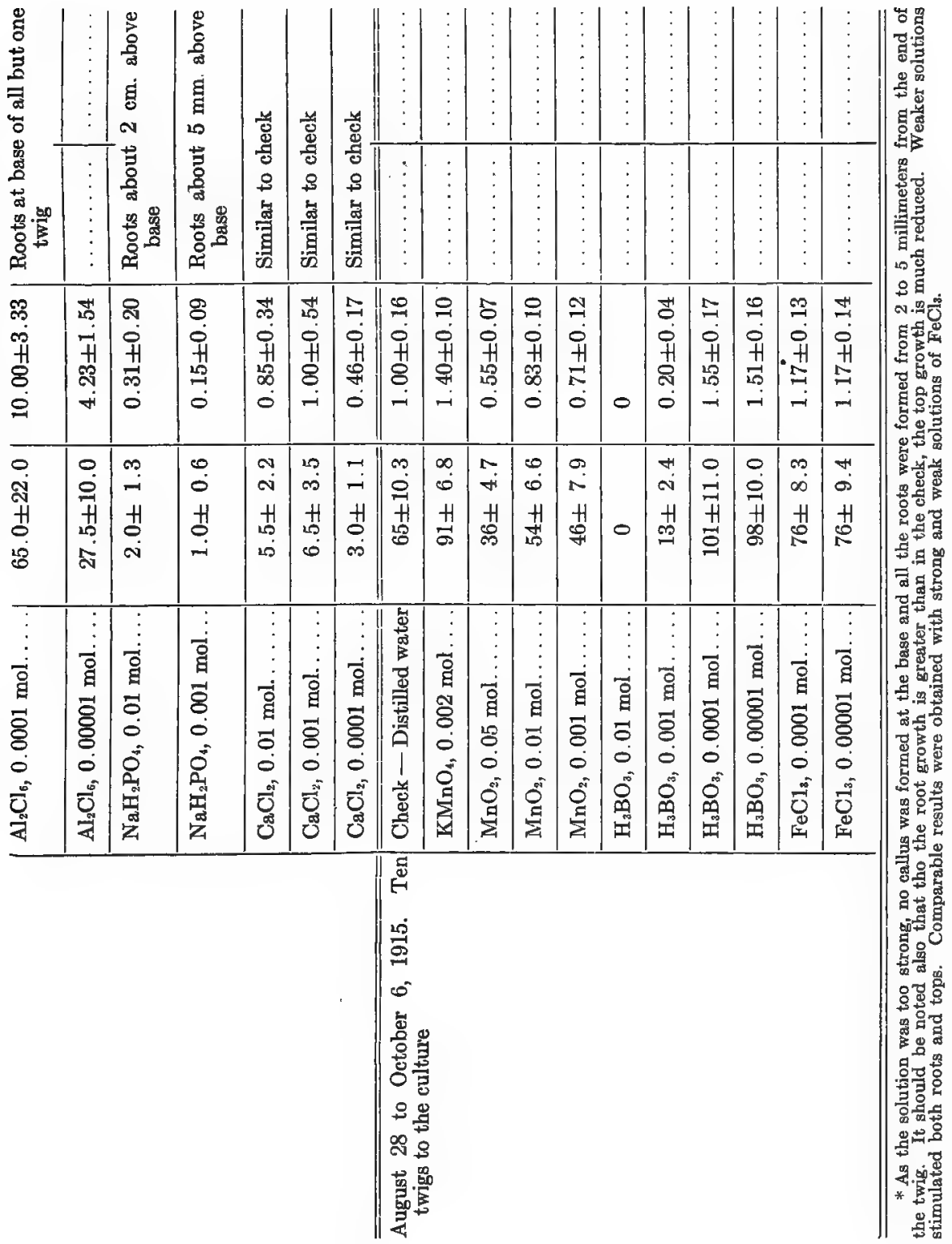




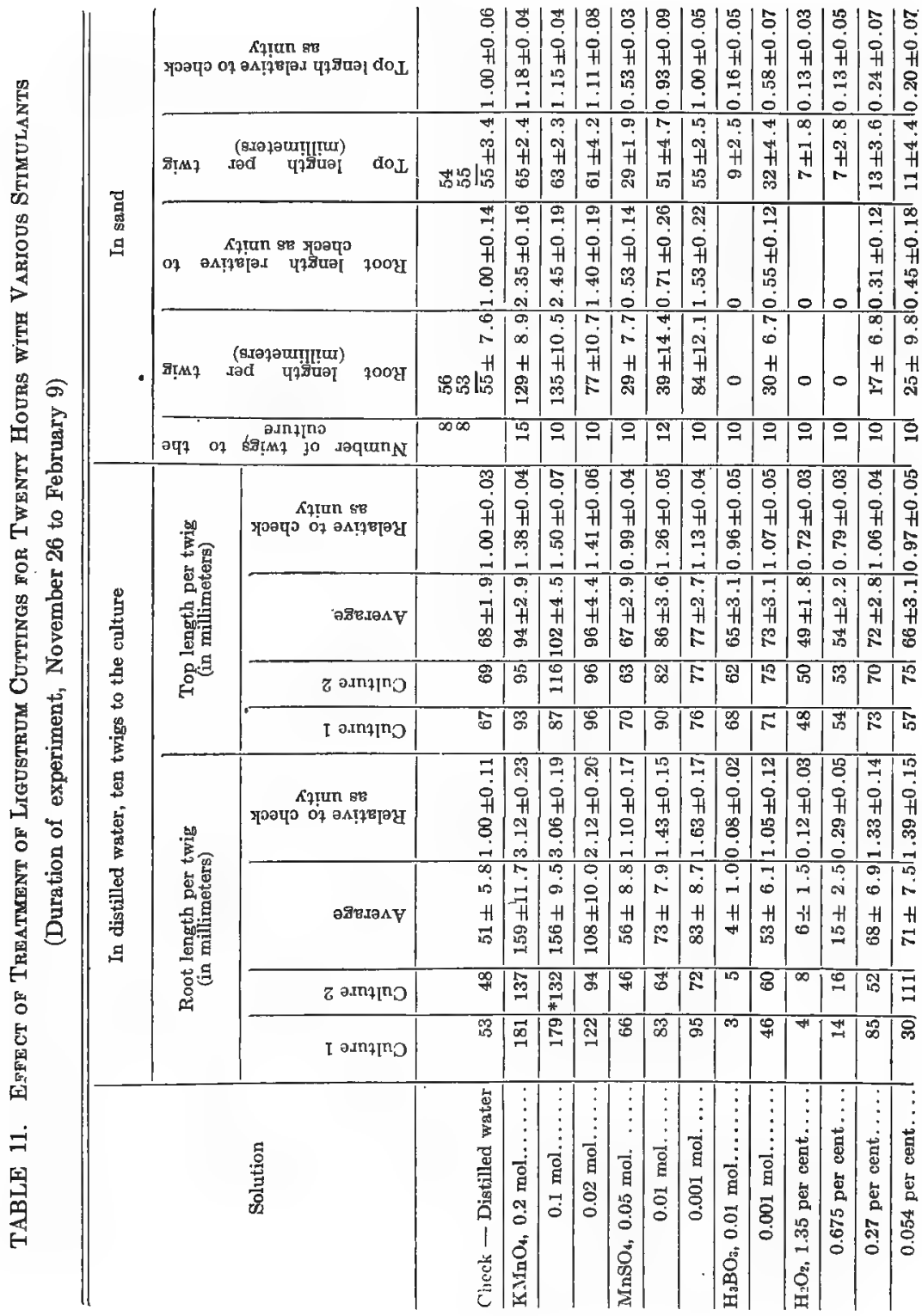




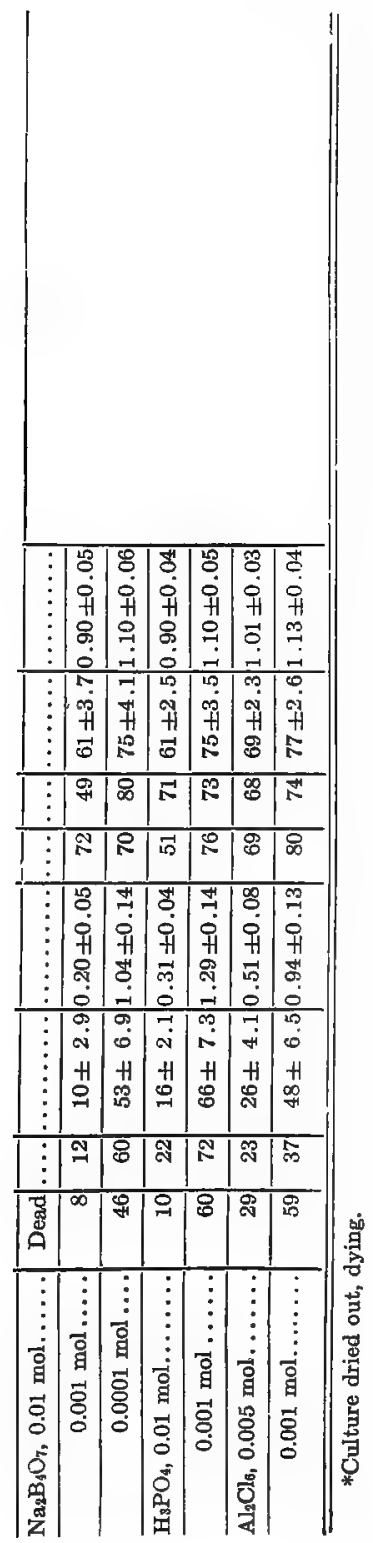


Calcium chloride and sodium acid phosphate, the one alternating with the other, followed in order of growth, while the check cultures in tap and distilled water were last, excepting those solutions that were distinctly toxic. Potassium permanganate was strongly toxic at the concentrations used. The weakest solution of ferric chloride alone showed marked stimulation. Apparently distilled water also was toxic, as the roots of the cuttings were stunted and produced short, thick branches. It is interesting to note that a supposedly toxic substance, such as boric acid, so markedly stimulates growth when alone in distilled water, especially when the latter itself is toxic.

In another experiment in which Iresine cuttings were placed in solutions of boric acid and ferric chloride, the latter caused greatly increased root growth while the former showed little or no effect.

\section{Experiments with woody cuttings}

Continuous treatment. - Cuttings of Ligustrum were placed at different times in various concentrations of the following compounds: $\mathrm{FeCl}_{3}$, $\mathrm{Fe}_{2}\left(\mathrm{SO}_{4}\right)_{3}, \mathrm{MnSO}_{4}, \quad \mathrm{MnO}_{2}, \mathrm{H}_{3} \mathrm{BO}_{3}, \mathrm{H}_{3} \mathrm{PO}_{4}, \mathrm{NaH}_{2} \mathrm{PO}_{4}, \mathrm{CaCl}_{2}, \mathrm{Al}_{2} \mathrm{Cl}_{6}$. The results in some cases were rather irregular. Manganese sulfate was usually toxic in these continuous treatments, but only a few concentrations were tried. Manganese dioxide showed stimulation in three experiments, had little effect in two, while in a sixth retardation was evident. Iron, either as $\mathrm{FeCl}_{3}$ or $\mathrm{Fe}_{2}\left(\mathrm{SO}_{4}\right)_{3}$, clearly showed stimulation in each of the three experiments in which it was used. Boric acid $\left(\mathrm{H}_{3} \mathrm{BO}_{3}\right)$ indicated stimulation in two experiments, but in a third showed slight retardation. Phosphoric acid $\left(\mathrm{H}_{3} \mathrm{PO}_{4}\right)$ caused stimulation in one experiment and injury in another. Aluminium chloride $\left(\mathrm{Al}_{2} \mathrm{Cl}_{6}\right)$ showed stimulation in the two experiments in which it was used. Some of the results obtained are recorded in table 10 (pages 106-7).

Limited treatment.- Cuttings were treated for twenty hours as indicated in table 11. One lot was then placed in sand and another in distilled water. The cuttings in distilled water were kept at a temperature about six degrees (centigrade) lower than the others, which accounts for their slower growth. The results of the limited treatment show a marked stimulation with permanganate and manganese sulfate, as regards both roots and tops. In the cuttings subsequently placed in sand, the boricacid and hydrogen-peroxide treatments retarded growth. 
As shown also by other experiments, manganese sulfate, as well as potassium permanganate, is more toxic when the twigs are placed in sand than when they are placed in water. This is probably due to the fact that when the twigs are rinsed and placed in water, the water further dilutes the small quantity of salt that may be carried over; while when the twigs are placed in sand, any such salt is not diluted but is perhaps concentrated as a result of slight evaporation from the surface of the stem. Weaker solutions of manganese sulfate, however, caused increased growth in the three experiments in which they were used.

\section{DISCUSSION OF STIMULATION BY COMPOUNDS OTHER THAN POTASSIUM PERMANGANATE}

Tho the results are not conclusive in all cases, there are at least indications of root stimulation in cuttings treated with $\mathrm{MnSO}_{4}, \mathrm{MnO}_{2}, \mathrm{FeCl}_{3}$, $\mathrm{Fe}_{2}\left(\mathrm{SO}_{4}\right)_{3}, \mathrm{Al}_{2} \mathrm{Cl}_{6}, \mathrm{H}_{3} \mathrm{PO}_{4}$, and $\mathrm{H}_{3} \mathrm{BO}_{3}$. The writer has found no references in literature concerning the effect of inorganic compounds on the root growth of cuttings. There are reported, however, a number of instances showing that certain of the above-mentioned substances have served to increase root growth in seedlings. A few of these are here considered.

\section{Manganese}

Loew (1904-05) reports that marked stimulation of roots of radishes resulted from the addition of manganese sulfate at the rate of 94 grams per square meter of soil. The treatment had no effect on top growth. Loew, as well as some of his Japanese students, reported several experiments indicating stimulation by manganese compounds, but no other mention is made of their effect on root growth. Furthermore, many of the conclusions are not very reliable, as they are based on results obtained with only a few individual plants with no duplication.

Micheels and De Heen (1906) report that colloidal suspensions of manganese have a marked stimulating effect on the roots of germinating wheat. Colloidal tin also has a stimulating effect on the roots of germinating peas, buckwheat, oats, and wheat (Micheels and De Heen, 1905), but the stimulation is less marked than that obtained with manganese (Micheels and De Heen, 1906). The seeds used in these experiments were soaked for about twenty-four hours in the solutions and were 
then suspended on a netting at the surface of the liquid. The treatment had no apparent effect on the percentage of germination; neither was stimulation obtained when the seeds were soaked for twenty-four hours and then suspended over distilled water. The authors explain the stimulation as due to an enzymatic effect of the colloidal suspension on the reserve food in the seed. They believe that it is purely a catalytic effect of suspended particles, as the metals were not taken up by the plant and the strength of the suspension was not diminished. They state that the stimulation could not have been due to substances in solution, for if the colloids were precipitated by the addition of an electrolyte the effect was nullified. It seems strange that the authors should explain the stimulation as due to the enzymatic effect of the suspension on the reserve food, when the stimulant was not absorbed by the plant and when no effect was produced if, after soaking, the seeds were suspended over distilled water. They did find a much increased root growth, and it would seem probable that this increased growth, with the resulting use of soluble food materials, might indirectly increase the rate of digestion by removing the products of digestion.

Brenchley (1910) found that root development of barley is stimulated when manganese sulfate is added to the nutrient solution.

In the Hawaii station report for 1910, Wilcox (1911) records results obtained by planting various types of crops on the manganiferous soils. He states that corn, rice, and other cereals, tobacco, cotton, legumes, garden vegetables, and fruit trees, all showed more or less of the characteristic yellowing of the tops, but the root systems were peculiar in that the root length and the fineness of small roots were strikingly greater than is found in root systems in ordinary soils. Wilcox says: "Apparently the extreme fineness of the roots is due to the lack of resistance which they meet in penetrating manganiferous soils."

Bertrand (1911) reports an increase in weight of roots of sugar beets, and also an increase in the percentage of sugar, as resulting from the addition of manganese compounds to the soil. He explains the stimulation as due to the increased oxidase activity with the resulting increase in respiration. In earlier publications (1896 and 1897) he showed that manganese is an active principle in various plant oxidases, especially laccase. 
The explanation previously given for the effect of treatments with potassium permanganate could be applied to the results obtained with manganese dioxide. The lack of as marked stimulation by the latter may have been due to the fact that the dioxide was not deposited in close proximity to the living tissues, as it was in the treatments with potassium permanganate. In this case the possible oxidizing compounds other than manganese dioxide, which Bunzell and Hasselbring (1917) found in solution after decomposition of potassium permanganate, would not be present.

Kelley (1912), in his work on the manganiferous soils of Hawaii, found a peculiar effect on the roots of plants growing in these soils. In most cases in which the manganese was not present in highly toxic concentrations, the roots were found to be highly developed, as appears from the following statement (Kelley, 1912:34): "Certain other plants, as for instance barley, wheat, oats, and jack beans were found to develop an unusual number of fine rootlets. In the case of barley this was especially noticeable." As stated earlier in the bulletin cited (page 26 of reference), "the root development [of corn] was found to be more extensive than in the normal soil," tho the top growth was retarded.

Lipman (1913), in determining the effects of salts of copper, zinc, and manganese on the growth of wheat and vetch in soil cultures, found that manganese gave the most marked stimulation, resulting in an increase in dry weight of both tops and roots.

Howard (1915b) found increased callusing of twigs of Fraxinus when these were coated with a paste of manganese dioxide. He explains this, however, as due to a heat effect resulting from the absorption of light. As the stems in the experiments here reported were not exposed to light, no such explanation is possible.

The stimulation by manganese sulfate may have been due to the manganese sulfate as such, or possibly to manganese dioxide deposited on or in the stem as a result of a reaction with the organic matter. The roots of plants grown in a solution containing manganese sulfate showed a browning, apparently due to the precipitation of manganese dioxide. Deatrick, in an investigation at this university, as yet unpublished, also " found a brown precipitate of the oxide of manganese on the roots of wheat seedlings grown in a solution containing manganese sulfate. The sulfate ion, as well as the manganese, may have played some rôle in the stimulation by manganese sulfate. 


\section{Iron and aluminium}

Bertrand (1911) has stated that compounds of iron, aluminium, and boron may act in a catalytic manner somewhat similar to that of manganese. Micheels (1905) earlier suggested such a possibility. The first two compounds may serve as oxygen carriers. Kastle (1910) cites a number of instances in which investigators have found iron to be closely associated with oxidation processes.

The iron as used in the present experiments was very evidently in the colloidal hydrated condition. When the solution was first made it was colorless, but within a few minutes the orange-yellow color of the suspended hydrate appeared, which was then easily precipitated by the addition of magnesium sulfate. The solution of 0.0001 molecular strength showed a very marked bluing of guaiacum tincture, as did also that of aluminium chloride of the same strength. The lack of stimulation in the limited treatments may possibly be explained as being due to the fact that no precipitate is formed in close proximity to the living tissues, as is the case in treatment with potassium permanganate, and since the action must be more or less continuous the short treatments are ineffectual. Micheels and De Heen (1905) found similar results with colloidal tin. When the seedlings were entirely removed from the solution no stimulation resulted.

\section{Sulfur}

The stimulation obtained in the single treatment with ferric sulfate may have been due to the iron, as in the experiment with ferric chloride, or possibly the sulfate ion may have had some influence. It has been reported in several instances that sulfates increase root growth of seedlings, tho no explanation of this has as yet been offered.

Rusche (1912) found that as a rule sulfates are the most efficient salts in stimulating root growth in a number of plants. Chlorides, on the other hand, are the most harmful to root growth, while nitrates also have a retarding effect.

The tables given by Shedd (1914) indicate that the addition of certain sulfates increases root growth to a greater extent than it does top growth.

Hart and Tottingham (1915) found that certain plants, especially rape and red clover, show greatly increased root growth on the addition of sulfates. Calcium sulfate was the most efficient in this respect of those used. 


\section{Boric acid}

A few investigators (Agulhon, 1910, and others) have reported that boric acid stimulates root development in seedlings. Brenchley (1914) found that boric acid has a marked stimulating action on the roots of peas, radishes, wheat, and turnips.

\section{Phosphates}

It is generally understood in field practice that phosphates have a beneficial effect on root growth. This has been reported on by Lawes (1847), Russell (1912), Ames and Boltz (1915), and others. In some preliminary work with seedlings it has been found that phosphates, and especially sodium phosphate, markedly increase root growth of flax, alfalfa, and Canada field pea.

Phosphates are not generally considered as oxygen carriers. Leonid Iwanoff (1910) has found, however, that phosphates increase respiration of living seeds and of seeds killed by treatment with toluol. This was determined by measuring the rate of carbon dioxide production. Dibasic phosphates were more efficient than monobasic. Nicolaus Iwanoff (1911) found that phosphates have no effect on the respiration of living seeds or living stem tips, but that they do increase the carbon dioxide production from tissues that have been killed by freezing or by treatment with toluol. He and others have obtained similar results also with yeast. Dibasic phosphates were very efficient, while monobasic phosphates, on the other hand, retarded carbon dioxide production. Iwanoff has shown that the increase in carbon dioxide production brought about by phosphates is probably due, not to an increase in oxidation. but to an increase in anaerobic splitting.

From experiments with seedlings the writer has found monobasic phosphates to be more efficient than dibasic in stimulating root growth.

Schreiner, Sullivan, and Reid (1910) state that phosphates markedly increase oxidation by roots and soils, but whether the oxidation in this case is a result of increased root activity, or its cause, is not certain. As far as is indicated by the results of the present investigation, phosphates have no marked effect on root growth of woody cuttings. Tho the writer has little proof as to the mechanism or the fundamentals concerned, he is of the opinion that phosphates as contrasted with nitrates may in some way check the continued growth of tops and thus allow for a greater 
supply of organic matter to be transported to and used by the roots. The effect on roots, therefore, would be chiefly secondary. This point is being tested experimentally.

\section{PART II. ORGANIC NUTRITION OF CUTTINGS}

\section{REVIEW OF LITERATURE}

Faivre (1871) clearly demonstrated that root formation in woody cuttings is dependent on the food stored in the twig. He found also that this food, as starch, disappears from the cutting when growth starts, apparently being used in callus and root formation, or, if the tops appear first, in their production. He demonstrated that this food passes downward to the roots thru the phloem region. The fact that elaborated food passes downward to the roots thru the phloem tissues was recognized by Knight (1801) early in the nineteenth century. The paper he published at that time states that when a tree is ringed the callus develops only on the upper side of the cut, and that growth of the stem also occurs only above the cut. He explains this on the ground that the food substances used in tissue building come from above. Later (1809) he stated that substances used in forming roots must come down thru the bark region, as roots formed on a ringed twig will develop only above the cut. It was clearly recognized by Sorauer (1895) that the roots of woody cuttings are dependent on a supply of food stored in the twig, and those of herbaceous forms on food supplied by attached leaves. Küster (1903) states that callus formation is dependent on the amount of food available.

Boehm (1883), Meyer (1886), Acton (1890), and others, have shown that severed shoots or leaves, if placed in various sugars and other organic compounds, will absorb some of these and store them as starch in the leaves or the stems. It occurred to the writer, therefore, that possibly immature twigs could thus be caused to take up and store a reserve supply of food. If the food were thus stored, it might be possible to decrease the leaf surface and the light intensity, thus decreasing the attendant labor of regulating humidity and light while retaining the advantages to be gained by using herbaceous or immature twigs. The treatment might also increase the vigor of cuttings that root rather readily, and lengthen the season during which woody cuttings can be taken. It was found that Ligustrum cuttings taken before the middle of October were immature and produced weak plants, while those taken the last of November had passed the rest 
period, which resulted in rapid growth of tops when the twigs were placed in the cutting bench. This resulted in no injury to the quick-rooting Ligustrum cuttings, but many slow-rooting forms would fail to root under such conditions. If immature cuttings could be taken early in the autumn and caused to root as well as mature cuttings taken later, they would have a longer time in which to become well rooted before winter and before the end of the rest period.

Figures given by Dachnowski (1914) showing results when tomato cuttings were placed in a large variety of solutions, indicate that the addition of glycocoll markedly increases root growth and that cane sugar has a somewhat similar effect.

Knudson (1916) found that an increase in sugar content of the nutrient solution very markedly increases root growth in various seedlings when grown under sterile conditions. The top growth also is benefited, but the roots respond especially well to an increased supply of carbohydrates.

EFFECT OF LIMITED TREATMENT WITH SUGAR SOLUTIONS ON IMMATURE TWIGS

Treatment with different concentrations

On August 30 cuttings were taken from large succulent leaders on Ligustrum bushes. Six leaves were left on each twig, and there were four twigs in a culture. The twigs were placed for three days in the solutions indicated in table 12, after which the leaves were removed and the twigs were rinsed and placed in distilled water.

TABLE 12. EFfect of Sugar Solutions o.j Immamure Twigs

(Duration of experiment, August 30 to October 15, 1915)

\begin{tabular}{|c|c|c|c|c|}
\hline \multirow{2}{*}{ Solution } & \multicolumn{4}{|c|}{$\begin{array}{l}\text { Average length of roots per twig } \\
\text { (in millimeters) }\end{array}$} \\
\hline & $\begin{array}{l}\text { Cul- } \\
\text { ture } 1\end{array}$ & $\begin{array}{l}\text { Cul- } \\
\text { ture } 2\end{array}$ & Average & $\begin{array}{l}\text { Relative } \\
\text { to check } \\
\text { as unity. }\end{array}$ \\
\hline $\begin{array}{l}\text { Check - Distilled water . } \ldots \ldots \ldots \ldots \ldots \ldots \\
\text { Cane sugar, } 1 \text { per cent. } \ldots \ldots \ldots \ldots \ldots \ldots \ldots \\
\text { Cane sugar, } 5 \text { per cent. } \ldots \ldots \ldots \ldots \ldots \ldots \ldots \\
\text { Cane sugar, } 10 \text { per cent } \ldots \ldots \ldots \ldots \ldots \ldots \ldots\end{array}$ & $\begin{array}{r}4 \\
20 \\
35 \\
58\end{array}$ & $\begin{array}{r}4 \\
15 \\
19 \\
81\end{array}$ & $\begin{array}{l}4 \pm 1.5 \\
17.5 \pm 3.3 \\
27.0 \pm 7.4 \\
69.5 \pm 16.3\end{array}$ & $\begin{array}{r}1.00 \pm 0.38 \\
4.37 \pm 0.84 \\
6.75 \pm 1.85 \\
17.37 \pm 4.08\end{array}$ \\
\hline
\end{tabular}


The table indicates that when unripe succulent twigs are allowed to stand in sugar solutions for a short time, the resulting root growth is markedly increased, the greatest increase in this case being shown by the twigs in the strongest solution.

\section{Treatment for one day, for two days, and for twelve days}

On the same date as that of the preceding experiment, immature twigs were treated with sugar solutions as indicated in table 13 and were then rinsed and placed in sand in the cutting bench. These twigs were immature terminal parts, less succulent than those used in the preceding experiment. The leaves were removed before the twigs were placed in the solution.

Table 13. Effect of Duration of Treatment with Sugar on Ligustrum Cututings (Duration of experiment, August 30 to October 30, 1915)

\begin{tabular}{|c|c|c|c|c|c|}
\hline 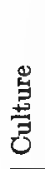 & Treatment & $\begin{array}{l}\text { Number } \\
\text { of twigs } \\
\text { used }\end{array}$ & $\begin{array}{c}\text { Number } \\
\text { of twigs } \\
\text { dead }\end{array}$ & $\begin{array}{l}\text { Average } \\
\text { total root } \\
\text { length } \\
\text { per twig } \\
\text { (millimeters) }\end{array}$ & $\begin{array}{l}\text { Average } \\
\text { total root } \\
\text { length per } \\
\text { living twig } \\
\text { (millimeters) }\end{array}$ \\
\hline $\begin{array}{l}1 \\
2 \\
3 \\
4 \\
5\end{array}$ & $\begin{array}{l}\text { Distilled water one day ........... } \\
\text { Cane sugar, } 5 \text { per cent, one day.... } \\
\text { Cane sugar, } 5 \text { per cent, two days... } \\
\text { Distilled water twelve days...... } \\
\text { Cane sugar, } 5 \text { per cent, twelve days }\end{array}$ & $\begin{array}{l}18 \\
19 \\
19 \\
20 \\
21\end{array}$ & $\begin{array}{r}9 \\
14 \\
0 \\
13 \\
0\end{array}$ & $\begin{array}{r}43 \pm 11.9 \\
48 \pm 11.5 \\
\mathrm{r} 83 \pm 16.6 \\
6 \pm 2.3 \\
50 \pm 11.2\end{array}$ & $\begin{array}{r}86 \\
182 \\
183 \\
17 \\
50\end{array}$ \\
\hline
\end{tabular}

Two twigs of the check and two of those in 5-per-cent cane sugar were sectioned on the fifth day and tested for starch. The checks showed no. starch either at the base, at 2 centimeters above the base, or at 15 centimeters above the base, while the twigs from the sugar solution showed starch at all three levels. Sugar mast therefore have been absorbed and stored in the twigs as starch. In this lot many of the twigs apparently did not have sufficient food stored to allow for any growth, as ten out of eighteen in the better of the check cultures failed to develop roots. When allowed to stand in a sugar solution for two days or more, sufficient food was stored to allow growth of both roots and tops. The tops were not measured, as the new shoots were very short with but few leaves. The condition of the cuttings at the time when the roots were measured is shown in figure 7 . 


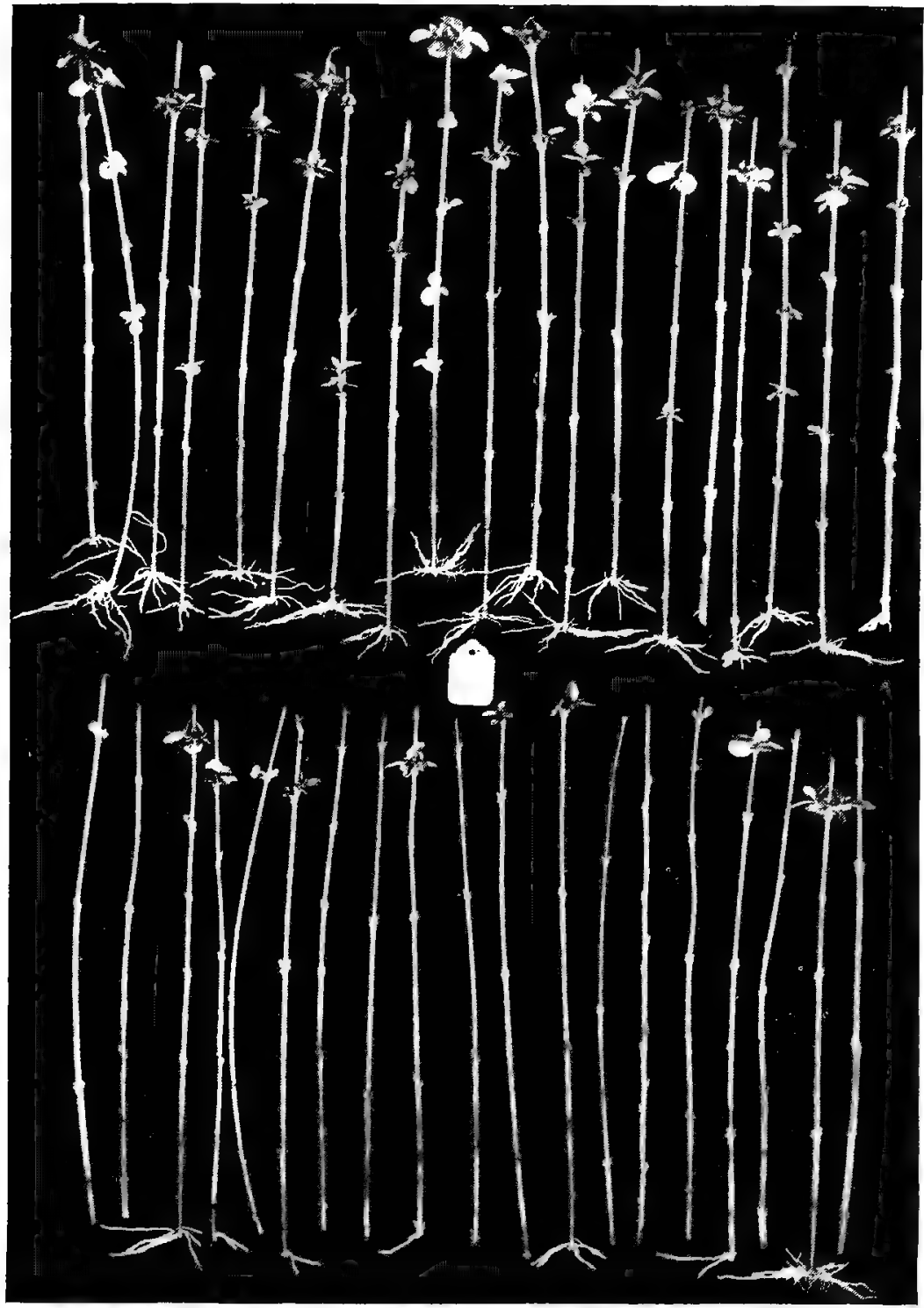

Fig. 7. EFFECT OF SUGAR ON ROOT FORMATION IN IMMATURE TWIGS Upper row: Cuttings left for two days in 5-per-cent cane sugar, then placed in sand Lower row: Cuttings left in water for one day, then placed in sand 
Influence of solutions of sugar for one, five, and fourteen days, respectively, in an incubator

In another experiment more fully ripened cuttings were placed in tumblers containing 100 cubic centimeters of solution, and these were set in incubators at the constant temperatures given in table 14. After the treatment the twigs were rinsed and placed in distilled water.

Table 14. Influence of Solutions of Cane Sugar at Different Temperatures and for Different Lengths of Time

(Duration of experiment, September 10 to October 30, 1915. Ten cuttings of Ligustrum to the culture)

\begin{tabular}{|c|c|c|c|c|c|}
\hline Solution & $\begin{array}{c}\text { Temper- } \\
\text { ature } \\
\text { (centi- } \\
\text { grade) }\end{array}$ & $\begin{array}{l}\text { Duration } \\
\text { of } \\
\text { treatment }\end{array}$ & $\begin{array}{c}\text { Root } \\
\text { length } \\
\text { per twig } \\
\text { (milli- } \\
\text { meters) }\end{array}$ & $\begin{array}{l}\text { Num- } \\
\text { ber of } \\
\text { twigs } \\
\text { rooted }\end{array}$ & $\begin{array}{l}\text { Num- } \\
\text { ber of } \\
\text { twigs } \\
\text { dead }\end{array}$ \\
\hline 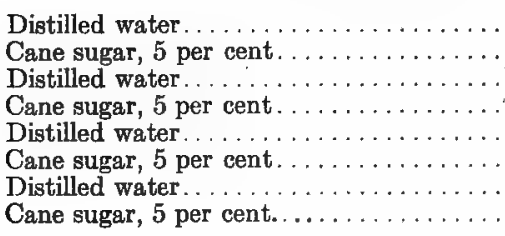 & $\begin{array}{l}30^{\circ} \\
30^{\circ} \\
35^{\circ} \\
35^{\circ} \\
30^{\circ} \\
30^{\circ} \\
30^{\circ} \\
30^{\circ}\end{array}$ & $\begin{array}{l}24 \text { hours } \\
24 \text { hours } \\
24 \text { hours } \\
24 \text { hours } \\
5 \text { days } \\
5 \text { days } \\
14 \text { days } \\
14 \text { days }\end{array}$ & $\begin{array}{r}22.0 \\
40.0 \\
148.0 \\
127.0 \\
165.5 \\
268.5 \\
4.5 \\
191.0\end{array}$ & $\begin{array}{r}5 \\
5 \\
8 \\
10 \\
8 \\
10 \\
2 \\
10\end{array}$ & $\begin{array}{l}3 \\
2 \\
2 \\
0 \\
2 \\
0 \\
2 \\
0\end{array}$ \\
\hline
\end{tabular}

In each case at $30^{\circ} \mathrm{C}$. the twigs in the sugar solutions showed the greater root development - an increase, as compared to the corresponding check in distilled water, of from 62 to 4144 per cent. At $35^{\circ}$, however, the sugar had a slight retarding effect. In each of the checks from two to three twigs died, while all the treated twigs not only lived but also formed roots, with the exception of two twigs in the 24-hours treatment at $30^{\circ}$. The twigs left in the sugar solution for fourteen days showed a very marked swelling at the base extending from 3 to 4 centimeters above the lower end. This swelling was in the cortex region, which showed also deep longitudinal splits. None of the checks exhibited such swellings. A similar but less pronounced swelling was apparent in most of the twigs used in other experiments when they were left in sugar for several days. 


\section{EFFECT OF CONTINUOUS TREATMENT WITH SUGAR SOLUTIONS}

Effect of sugar alone on immature twigs

The experiments just reported indicate that immature twigs left for a short time in sugar solutions will absorb part of the sugar and store it in the stems as starch. The resulting root growth is very much greater than in untreated twigs. The effect of sugar solutions on immature twigs under continuous treatment was studied in the following experiment.

Immature terminal parts of Ligustrum twigs, 20 centimeters long, were taken on September 4, and were treated as indicated in table 15 and then set away in the dark. No roots were developed on the twigs left continuously in 5-per-cent cane sugar. Apparently the growth of microorganisms had produced toxic compounds which inhibited growth. The twigs that were removed from the sugar at the end of eleven days eventually developed roots. All the check twigs died.

Table 15. Effect of Sugar Solutions on Immature Cutrings of Ligustrum under Continuous Treatment

(Duration of experiment, September 4 to November 10, 1915)

\begin{tabular}{|c|c|c|c|c|}
\hline Solution & $\begin{array}{l}\text { Condition on } \\
\text { September } 15\end{array}$ & $\begin{array}{l}\text { Condition on } \\
\text { November } 10\end{array}$ & $\begin{array}{l}\text { Num- } \\
\text { ber of } \\
\text { twigs } \\
\text { used }\end{array}$ & $\begin{array}{l}\text { Num- } \\
\text { ber of } \\
\text { twigs } \\
\text { dead }\end{array}$ \\
\hline Distilled water. & $\begin{array}{l}\text { No starch at base or at } \\
10 \mathrm{~cm} \text {. above base. } \\
\text { Not changed }\end{array}$ & No roots...... & 13 & 13 \\
\hline 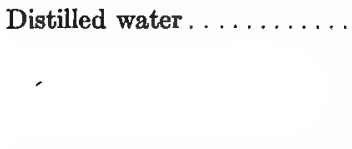 & $\begin{array}{l}\text { No starch at base or at } \\
10 \mathrm{~cm} \text {. above base. } \\
\text { Changed to fresh dis- } \\
\text { tilled water at this } \\
\text { time }\end{array}$ & No roots..... & 14 & 14 \\
\hline Cane sugar, 5 per cent. . . . & $\begin{array}{lll}\text { Abundant starch at } \\
\text { base, less at } 10 \text { em. } \\
\begin{array}{l}\text { above base. } \\
\text { changed }\end{array}\end{array}$ & No roots.... & 14 & 6 \\
\hline Cane sugar, 5 per cent. .... & $\begin{array}{l}\text { Abundant starch at } \\
\text { base, less at } 10 \mathrm{~cm} \\
\text { above base. Changed } \\
\text { to distilled water at } \\
\text { this time }\end{array}$ & $\begin{array}{l}7 \text { twigs rooted, } \\
\text { average length } \\
39 \mathrm{~mm} \text {. per } \\
\text { twig }\end{array}$ & 14 & 8 \\
\hline
\end{tabular}


Effect of sugar with manganese dioxide, boric acid, or ferric chloride

Since the cuttings were injured when left continuously in sugar solutions, it was thought possible that the toxicity might be reduced by the addition of some compound which might either retard the growth of bacteria or oxidize toxic compounds produced by them. For that reason the following experiment was undertaken, in which manganese dioxide and boric acid were added to the sugar solutions. On October 6 the twigs in the poorer culture of each pair were rinsed and placed in fresh water. Final notes were taken on December 16, and the results of the experiment appear in table 16.

As shown by table 16, the stronger solutions of sugar retarded or inhibited root growth. The weakest solution, 0.1 per cent, however, caused an increased development. The presence of manganese dioxide resulted injuriously, either when used alone or when combined with sugar. Boric acid, on the other hand, stimulated growth, as has previously been shown. It also partially overcame the inhibiting effect resulting from the presence of sugar.

The retardation of root growth in the presence of sugar is probably due to the formation of some toxic compounds resulting from the action of bacteria and fungi. In several of the cultures alcohol could be detected both by its odor and by iodoform test. Unless the period is too long, the inhibiting effect of sugar continues only as long as the twigs are left in the solution; after being rinsed and placed in fresh water, as indicated by the table, many twigs in which the root growth had formerly been inhibited by the sugar developed normal roots, and judged from their appearance some of these twigs had even greater root development than had the checks.

In another experiment, started on October 15, fully matured cuttings of Ligustrum were allowed to stand continuously in sugar solutions alone, and also in sugar to which was added ferric chloride, boric acid, or manganese dioxide. In every case the presence of sugar varying from 0.04 to 0.0004 molecular strength, retarded root formation. The presence of the inorganic compounds seemed even to increase the retarding effect of the sugar. When potassium permanganate was present with the sugar, however, the retarding effect of the latter was largely overcome. 
TABLE 16. Influence of Sugar Alone, and Together with $\mathrm{MnO}_{2}$ or $\mathrm{H}_{3} \mathrm{BO}_{3}$, on Cuttings of Ligustrum

(Continuous treatment from August 28 to October 6. Ten twigs per culture. On October 6 the poorer culture of each pair was rinsed and placed in fresh water)

\begin{tabular}{|c|c|c|c|c|c|}
\hline \multirow{2}{*}{ Solution } & \multicolumn{3}{|c|}{$\begin{array}{c}\text { Root length per twig (in millimeters) } \\
\text { October } 6\end{array}$} & \multicolumn{2}{|c|}{ Notes on appearance December 16} \\
\hline & $\begin{array}{c}\text { Cul- } \\
\text { tures } \\
1 \text { and } 2\end{array}$ & Average & $\begin{array}{l}\text { Relative } \\
\text { to check } \\
\text { as unity }\end{array}$ & $\begin{array}{l}\text { Solution } \\
\text { unchanged }\end{array}$ & $\begin{array}{c}\text { Twigs placed } \\
\text { in fresh water } \\
\text { October } 6\end{array}$ \\
\hline Check - Distilled water. & $\begin{array}{l}62 \\
67\end{array}$ & $65 \pm 10.3$ & $1.00 \pm 0.16$ & Fair roots...... & Fair roots \\
\hline Cane sugar, 5 per cent. . & $\begin{array}{l}0 \\
0\end{array}$ & 0 & 0.00 & Very few roots. . & Large roots \\
\hline 2 per cent... & $\begin{array}{l}6 \\
2\end{array}$ & $4 \pm 1.4$ & $0.06 \pm 0.02$ & Very few roots. . & Large roots \\
\hline 1 per cent... & $\begin{array}{l}\text { g8 } \\
17\end{array}$ & $23 \pm 5.2$ & $0.35 \pm 0.08$ & Very few roots.. & Large roots \\
\hline 0.1 per cent. & $\begin{array}{l}120 \\
107 \\
\end{array}$ & $114 \pm 6.9$ & $1.75 \pm 0.10$ & 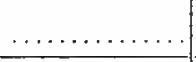 & $\ldots \ldots \ldots$ \\
\hline $\mathrm{MnO}_{2}, 0.05 \mathrm{~mol} . \ldots$. & $\begin{array}{l}40 \\
32\end{array}$ & $36 \pm 4.7$ & $0.55 \pm 0.07$ & Fair roots..... & Fair roots \\
\hline $0.01 \mathrm{~mol}$. & $\begin{array}{l}\mathbf{5 7} \\
\mathbf{5 0}\end{array}$ & $54 \pm 6.6$ & $0.83 \pm 0.10$ & 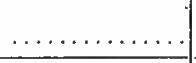 & $\ldots \ldots \ldots$ \\
\hline $0.001 \mathrm{~mol} .$. & 46 & $46 \pm 7.9$ & $0.71 \pm 0.12$ & & $\ldots \ldots \ldots$ \\
\hline $\begin{array}{r}\mathrm{MnO}_{2}, 0.05 \text { mol., and cane } \\
\text { sugar, } 2 \text { per cent...... }\end{array}$ & $\begin{array}{l}0 \\
0\end{array}$ & 0 & 0.00 & No roots....... & Few roots \\
\hline $\begin{array}{c}\mathrm{MnO}_{2}, 0.01 \mathrm{~mol} \text {, and cane } \\
\text { sugar, } 2 \text { per cent...... }\end{array}$ & $\begin{array}{l}0.3 \\
0.1 \\
\end{array}$ & $0.2 \pm 0.1$ & $0.003 \pm 0.002$ & Few roots...... & Fair roots \\
\hline $\begin{array}{l}\mathrm{MnO}_{2}, 0.001 \text { mol., and } \\
\text { cane sugar, } 2 \text { per cent. }\end{array}$ & $\cdots \ddot{0}^{\prime}$ & 0 & 0.00 & $\ldots \ldots \ldots$ & $\ldots \ldots \ldots$ \\
\hline $\mathrm{H}_{3} \mathrm{BO}_{3}, 0.001 \mathrm{~mol}$ & $\begin{array}{r}18 \\
8\end{array}$ & $13 \pm 2.4$ & $0.20 \pm 0.04$ & Fair roots..... & Fair roots \\
\hline $0.0001 \mathrm{~mol} \ldots \ldots$ & $\begin{array}{r}110 \\
92 \\
\end{array}$ & $101 \pm 11.0$ & $1.55 \pm 0.17$ & Fair roots.... & Very large roots \\
\hline $0.00001 \mathrm{~mol} \ldots$ & $\begin{array}{r}106 \\
90\end{array}$ & $98 \pm 10.3$ & $1.51 \pm 0.16$ & $\ldots \ldots \ldots \ldots$ & $\ldots \ldots \ldots$ \\
\hline $\begin{array}{l}\mathrm{H}_{8} \mathrm{BO}_{3}, \quad 0.001 \text { mol., and } \\
\text { cane sugar, } 2 \text { per cent. }\end{array}$ & $\begin{array}{l}7 \\
3\end{array}$ & $5 \pm 1.7$ & $0.08 \pm 0.03$ & Dead . . . . . . . & Fair roots \\
\hline $\begin{array}{l}\mathrm{H}_{3} \mathrm{BO}_{3}, 0.0001 \text { mol., and } \\
\text { cane sugar, } 2 \text { per cent. }\end{array}$ & $\begin{array}{r}34 \\
7\end{array}$ & $21 \pm 6.1$ & $0.32 \pm 0.09$ & Few roots..... & Fair roots \\
\hline
\end{tabular}

EFFECT OF LIMITED TREATMENT WITH SUGAR SOLUTIONS ON MATURER CUTTINGS

The experiments thus far reported have shown that beneficial results can be obtained by treating immature cuttings of Ligustrum for from 
one to fourteen days with sugar solutions, but that continuous treatment with the same solutions tends to retard root formation in both immature and mature cuttings. The immature cuttings used in the experiments just discussed were found to have little starch stored in the stem. As shown by other experiments, less striking results were obtained when maturer twigs were used. In these experiments, partly matured upper parts of the twigs were used, but these were taken later in the season and had been subjected to several frosts.

Six experiments were set up in which mature Ligustrum cuttings were treated for from two to fifteen days with sugar of from 0.2 to 0.4 molecular concentration. No very marked effects on root growth were obtained at any time when mature cuttings were treated with sugar. Usually the treatment resulted in a somewhat increased top growth, but this was not very striking. There was, on the other hand, a peculiar and marked effect on the nature of the top growth. Normally the buds at the uppermost node of each cutting produce the strongest shoots, while the buds at the other nodes remain dormant or produce only weak shoots. For the twigs treated with sugar, however, there was in each

TABLE 17. Effect of Various Organic Compounds on Mature Cuttings of LIGUSTRUM

(Twigs cut on December 8, 1915, placed in solution for two days, then rinsed and placed in sand. Buds started on December 27. Measurements taken on March 10, 1916)

\begin{tabular}{|c|c|c|c|c|c|c|c|c|c|c|}
\hline \multirow{3}{*}{ Solution } & \multirow{3}{*}{$\begin{array}{l}\text { Num- } \\
\text { ber of } \\
\text { twigg } \\
\text { used }\end{array}$} & \multicolumn{2}{|c|}{ Roots } & \multicolumn{7}{|c|}{$\begin{array}{l}\text { Top measurements } \\
\text { (in millimeters) }\end{array}$} \\
\hline & & \multirow{2}{*}{$\begin{array}{c}\text { Dry } \\
\text { weight } \\
\text { perr } \\
\text { cutting } \\
\text { (grams) }\end{array}$} & \multirow{2}{*}{$\begin{array}{c}\text { Rela- } \\
\text { tive to } \\
\text { cheok } \\
\text { as } \\
\text { unity }\end{array}$} & \multirow{2}{*}{$\begin{array}{c}\text { Length } \\
\text { at } \\
\text { first } \\
\text { node }\end{array}$} & \multirow{2}{*}{$\begin{array}{c}\text { Length } \\
\text { at } \\
\text { other } \\
\text { nodes }\end{array}$} & \multirow{2}{*}{$\int \begin{array}{c}\text { Total } \\
\text { length }\end{array}$} & \multicolumn{4}{|c|}{$\begin{array}{l}\text { Length at each of the first } \\
4 \text { nodes beginning at top }\end{array}$} \\
\hline & & & & & & & 1 st & $2 d$ & $3 d$ & 4th \\
\hline Distilled water. & 23 & 0.0440 & 1.00 & 47.0 & 0.4 & 47.4 & 47.0 & 0.4 & 0.0 & 0.0 \\
\hline Glucose, $0.4 \mathrm{~mol}$. & 23 & 0.0400 & 0.91 & 26.7 & 21.3 & 48.0 & 26.7 & 20.2 & 1.1 & 0.0 \\
\hline Glucose, $0.2 \mathrm{~mol} .$. & 24 & 0.0497 & 1.13 & 46.7 & 4.2 & 50.9 & 46.7 & 3.8 & 0.4 & 0.0 \\
\hline Saccharose, $0.4, \mathrm{~mol} . . .$. & 24 & 0.0325 & 0.74 & 14.2 & 25.9 & 40.1 & 14.2 & 19.0 & 5.4 & $\overline{1.5}$ \\
\hline Saccharose, $0.2 \mathrm{~mol} . . .$. & 25 & 0.0417 & 0.95 & 37.8 & 12.6 & 50.4 & 37.8 & 10.6 & 1.4 & $\overline{0.6}$ \\
\hline Asparagin, 0.25 per cent. & 24 & 0.0361 & 0.82 & 36.3 & 1.3 & 37.6 & 36.3 & 1.3 & 0.0 & 0.0 \\
\hline Peptone, 1 per cent..... & 26 & 0.0382 & 0.87 & 35.0 & 16.5 & 51.5 & 35.0 & 16.5 & 0.0 & $\overline{0.0}$ \\
\hline Peptonc, 0.1 per cent ... & 26 & 0.0447 & 1.01 & 54.5 & 1.9 & 56.4 & 54.5 & 1.7 & 0.2 & 0.0 \\
\hline
\end{tabular}


of the six experiments, especially at the higher concentrations, a partial or total inhibition of shoot formation from the upper nodes, while the second or the third, or even the fourth, node below developed the more vigorous shoots. Similar results after treatment with cane sugar are shown in table 17 and in figure 8 . In this case, however, there is no increase in total top growth, as was found in most of the other experiments.

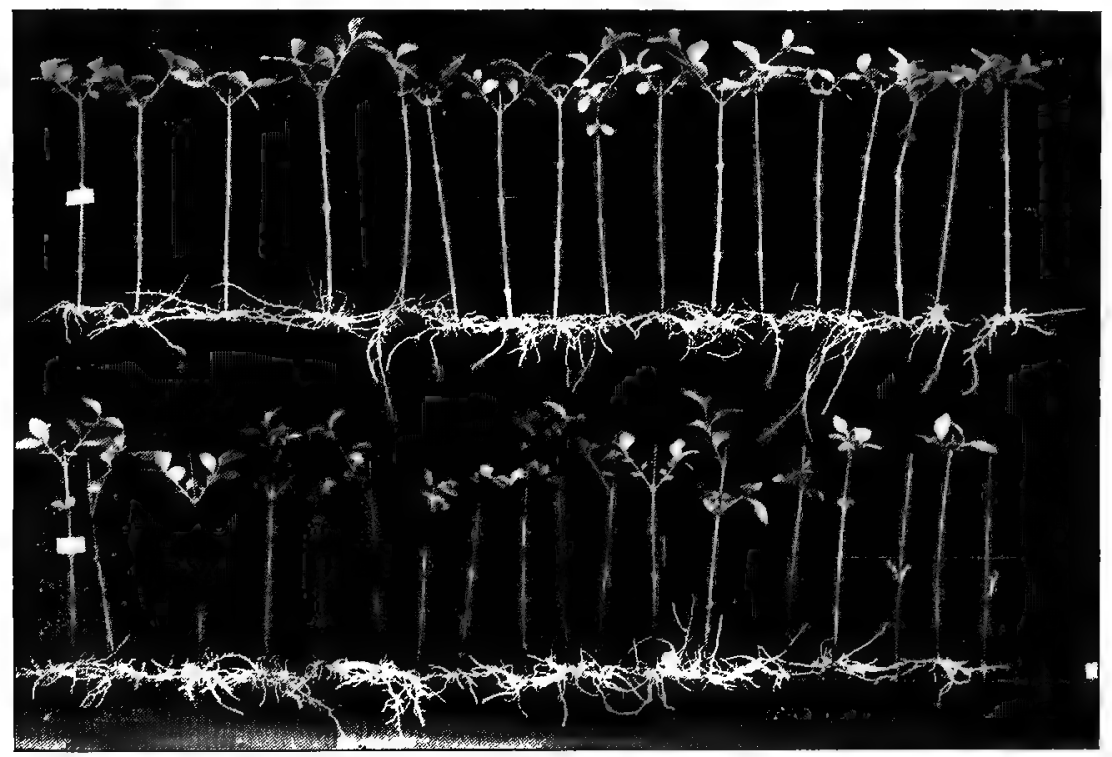

Fig. 8. EFFECT OF SUGAR SOLUTIONS ON MATURE CUTtiNGS OF LIGUSTRLi

Unper row: Check twigs left for two days in water, then placed in sand. In nearly evcry case shoots formed only at the uppermost node

Low $r$ row: Twigs left for two days in $0.4 \mathrm{~mol}$. cane sugar, then placed in sand. In the majority of twigs no shoots were produced at the uppermost node. Root growth was slightly retarded

\section{FORCIBLE INJECTION OF SUGAR SOLUTIONS}

Several preliminary experiments have been carried out in which sugar solutions were forcibly injected into the intercellular spaces of the stems of cuttings. The method is the same as that commonly used to increase penetration of killing fluids. The cuttings were immersed in the solutions, which were contained in heavy glass cylinders, and the pressure was then reduced by means of a suction pump. As a result the gases rapidly 
passed out of the stems, and when the pressure was restored the solutions were forced into the air spaces.

Cuttings of tomato and Iresine were found to have absorbed from 5 to 15 per cent of their dry weight of sugar from a 10-per-cent solution, while Ligustrum cuttings took up from 2 to 3 per cent of their dry weight under similar conditions. In one case untreated tomato cuttings contained sugar, measured as hexoses, to the extent of 7 per cent of their dry weight, while the treated cuttings contained sugar, measured as hexoses, to the extent of 17.7 per cent of their dry weight. The treatment, therefore, more than doubled the sugar content. 'The amount of sugar absorbed was approximately that which would be contained in the volume of solution injected:

As a result of the treatment, cuttings of tomato and Iresine showed an increase in root development over that in the checks. The results obtained with tomato are shown in table 18:

TABLE 18. Influence of Forcible Injection of Sugar Solutions into Tomato Cutrings

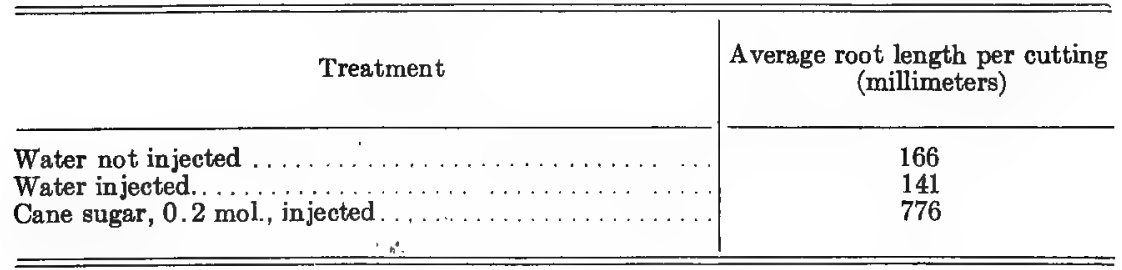

In cuttings of Ligustrum taken at the end of the rest period, the forcible injection of sugar caused a distinct retardation in bud development. This retardation was evident in all injected twigs irrespective of the solution used. The twigs treated started bud growth about one month later than twigs not placed under the suction pump, or about forty days after the cuttings were set out; while the buds of the twigs not treated developed in about ten days. Thus the filling of the air spaces with water apparently induces a rest period in twigs that have just passed the normal rest.

\section{DISCUSSION}

The experiments performed with distinctly immature twigs have shown that cane sugar may be taken up by such twigs and stored as starch, and 
that these twigs may live and may produce better roots than will untreated twigs. If maturer twigs are used, however, the increase in root growth is not so great and growth may even be retarded, especially if the twigs are placed in water instead of in sand. With these maturer twigs there is usually an increased top growth, and the treatment also determines to a certain extent the node at which the strongest shoot development will occur. Normally the buds at the uppermost nodes develop the strongest shoots, but in twigs treated with sugar the buds lower down are more likely to develop. Even in twigs placed in narrownecked flasks so that only the uppermost buds were exposed to the light, the lower, darkened buds developed.

Two possible explanations for this unusual development have occurred to the writer. The sugar may increase the concentration within the cells in the lower part of the stem, and this increased concentration and osmotic pressure may reduce the water content of the upper part; in practically all cases the upper part becomes withered and shrunken, but this withering is not evident until some time after the shoots are formed. On the other hand, the presence of sugar near the base may increase the available supply of organic matter for the lower buds, which may therefore grow earlier and more rapidly than the upper buds; this increased growth might result in the loss of both food and water from the upper part.

Howard $(1915 \mathrm{~b})$ reports that after the freezing of twigs the basal buds are more likely to develop than are the terminal buds. He found also that mechanical injury near or just below a bud results in the development of that bud. Furthermore, he has shown that mechanical injury increases the sugar content of a twig. In this respect the condition is similar to the sugar treatment here reported. But other conditions do not closely correspond, as the buds of the twigs treated with sugar were not in the resting condition as were those in Howard's experiments. Moreover, the mechanical injury may have increased the permeability, allowing for a loss of carbon dioxide and an increased supply of oxygen. The writer has found that if a twig which has passed the rest period is coated with paraffin, any bud, irrespective of its position, can be induced to develop while all the others remain dormant. This can be done by cutting the paraffin coating in such a way as to allow for aeration. The bud development cannot be explained as resulting from a mechanical weakening of the coat, for the surest way to induce development is to 
make an opening thru the paraffin to the leaf scar below a bud. This bud will then develop, breaking thru the unweakened paraffin layer above. This may be one of several factors to be considered in the development of buds at points where the subtending leaf is removed. Loeb (1915) has apparently overlooked this factor of aeration in explaining the development of shoots from buds on the side where a leaf has been removed. He found that even the petiole of a leaf, if left, will inhibit the development of the bud in its axil. It is quite possible that the petiole retards aeration thru the leaf scar.

In twigs left continuously in sugar solutions the rooting ability is usually markedly reduced. This is probably due, primarily, not to the sugar as such, but to the inhibitory by-products resulting from the action of microorganisms on this organic matter. Most of the culture solutions containing sugar for a prolonged period of time became badly contaminated and developed strong odors. In some of them alcohol could easily be detected either by the odor or by the iodoform test. The twigs from such cultures, when thoroly rinsed and placed in fresh water, eventually developed normal roots, and in some cases (tables 15 and 16) these roots were better developed than those of the check cultures. Twigs left in the sugar solutions too long, however, eventually died.

The poor results obtained in common practice when organic matter is present are probably due to the increased production, by organisms, of toxic decomposition compounds and carbon dioxide, and to the lessened supply of oxygen, rather than to the direct effect on the cuttings of the organic matter or of the microorganisms themselves.

Treatment with sugars is apparently of no value when mature twigs are used. Immature twigs, however, may be induced to root much better by such treatment. It would appear from table 12 that solutions stronger than most of those used might be more effective. Meyer (1886) found that leaves of Beta vulgaris formed little or no starch when placed in weak sugar solutions of about 1 per cent concentration, while stronger solutions - 10 and 20 per cent - increased starch formation.

When the air spaces of Ligustrum cuttings taken at the end of the normal rest period are filled with water or with sugar or salt solutions, by placing the twigs in the solutions under a suction pump a secondary rest period is apparently induced. It would seem that this excess of water and reduced aeration may favor the production and accumulation 
of certain toxic or inhibitory products of catabolism. If this is true it strengthens the belief of the writer that one of perhaps several causes of rest is the accumulation of inhibiting by-products of catabolism, not the accumulation of products of anabolism as suggested by Howard (1915 b). These inhibiting substances may be similar in nature to the "staling" substances produced by fungi as reported by Balls (1908), or to the toxic excreta from roots which have been under investigation by the men of the Bureau of Soils at Washington.

Other experiments on the rest period of plants, on organic nutrition of cuttings, and on this method of injection of organic and other substances, are being conducted, and therefore further data and discussion regarding these topics are reserved until later.

PART III. GENERAL DISCUSSION WITH REFERENCE TO PRACTICES COMMONLY FOLLOWED BY GREENHOUSE AND NURSERY MEN

In the propagation of plants by cuttings, certain general practices are observed by the majority of workers. The reasons given for such practices may vary widely with the individual growers. Furthermore, many of those most commonly given might be termed popular reasons, and have but very little scientific foundation. In some cases the real significance of the practices is recognized, but in many others the governing principles are apparently very poorly understood. The explanation for some of these practices, in so far as the present investigation has a bearing on them, are here briefly discussed.

It is usually recognized that good aeration is necessary, and for this reason a very porous medium is provided in which to start the cuttings. Sand is perhaps the commonest medium employed. It is generally agreed also that the medium must be well drained. This allows for better aeration, tho many persons think that water as such is directly injurious to the cuttings and may enter into and rot the twigs. Cuttings are sometimes started directly in water, in which case the water is held in shallow pans. These, of course, serve to give better aeration than deeper dishes would afford. In the case of cuttings that have been started in unglazed earthenware pots it has often been noted that those placed near the edge of the pot root better than those near the center. Bailey (1913:50) offers the explanation that the temperature is higher in that region. As an actual fact, however, the temperature near the edge of 
the pot is usually lower, due to the cooling effect of evaporation. Bailey suggests further that the deflection of nutrients ("plant food") to that region, due to evaporation, may increase growth. The experiments reported here, however, would contradict this. The more probable explanation, which Bailey also suggests, is that the soil is better aerated in that region. This may explain also the matting of roots next to the walls of the pot in the case of potted plants.

A practice commonly followed in the propagation of dormant cuttings from woody varieties is that of burying the cuttings for a time with the basal ends upward. Various reasons for this practice have been offered. It has been said that sap naturally flows upward, and therefore, if the cuttings are buried with the basal end up, the sap will flow into that part and form roots. Other reasons assigned are that the tops are thus kept dormant, or that the bottoms are thus directly heated (Bailey, 1913:57). It is questionable whether, at the time of year when the cuttings are thus buried, the temperature near the surface of the soil would be higher than that a few inches below. It is conceivable, however, that during the warm days in spring the temperature at the surface may exceed that below. It would seem that a very possible explanation might lie in the fact that twigs so treated would have much better aeration at the basal ends than if buried in an upright position.

Bottom heat is as a rule beneficial to root formation and is very necessary in the propagation of some varieties. This increased temperature, of course, tends to increase respiratory activity in those tissues that produce roots. The upper part of the stem, on the other hand, is left cool and remains in a comparatively quiescent state. When the temperature is approximately equal thruout the length of the stem, the tops of many varieties will develop and root formation is then inhibited. The higher temperature may serve also to decrease the retarding effect of any carbon dioxide that may be present. Such an effect on the germination of seedlings has been shown by the work of Kidd (1914).

It has been shown that the stimulation resulting from treatment with potassium permanganate is largely independent of any effect on the rest period of the twig. Nevertheless it is fairly clear that better results will be obtained with most woody cuttings if these are taken before the rest is over. As a general rule, woody cuttings are taken in the autumn before heavy frosts or freezes set in (Bailey, 1913, and Sim, 1904). One of the 
reasons put forward to explain this practice is that at that time of the year the sap is flowing downward and would therefore more readily form roots. The commonest reason given is that the cuttings will root better if a callus is allowed to form during the late autumn or early winter, while if no callus is formed the cutting will not root, or at least will not root so readily.

It would seem, from the results obtained in the present investigation, that this difference in rooting ability between twigs taken in the fall and in the spring is dependent on factors affecting the rest period of the buds, and therefore, indirectly, the food and water supply. Faivre (1871) has pointed out the fact that if woody cuttings are taken in autumn the tops will remain dormant, allowing the roots to form, while if the cuttings are taken in spring the tops will start and use up the stored food which would otherwise be available for root formation. This seems to be the most probable explanation, for, as stated earlier, as a rule the rooting process is slower than the growth of shoots, when the buds are not in the resting condition; the latter therefore develop more rapidly than do the roots, and, as sufficient water for the increased transpiration is not supplied, the shoots wither, causing the whole twig to wither at the same time. The increased top growth also reduces the amount of food available for root formation, as stated above.

Evidently it is not necessary to callus the cuttings before setting them out if they are taken before they have passed the resting stage. Some workers, however, say that the woody forms, which will not be winterkilled, will strike root just as well if left on the parent plant until spring. On the other hand, as the root development and the callus formation are apparently independent of the rest period, the taking of cuttings when the buds are dormant would allow for a longer period for the comparatively slow-growing roots and callus to start development, and thus insure a better root growth. If cuttings are taken in the fall and stored at low temperatures, they may have no apparent root development when set out in the spring and yet it is probable that incipient growth has begun.

Tho stimulation by potassium permanganate has been shown to be independent of an effect on the balance between root and top formation, such a balance can be partially controlled by selecting the right season for taking cuttings, as has just been discussed, or by regulating the tem- 
perature. As has already been stated, this balance can be controlled by the application of heat to the basal part of the cutting while the growth of the tops is retarded by continued low temperature.

As stated earlier, it has been recognized that in order to form roots a cutting must have available a sufficient amount of elaborated food. In the case of dormant woody cuttings, this food is stored in the twig, while herbaceous cuttings are dependent on such organic matter as is elaborated by the attached leaves. "The practice of ringing the twigs some time before making the cuttings, or ringing or notching before layering, serves merely to increase the supply of this food by checking its removal thru the phloem to other parts of the plant.

The explanation more commonly given for ringing, is that since this practice tends to increase callus formation it correspondingly increases root formation, because a callus must be formed before the roots will develop. As Corbett (1897) has stated, however, and as the writer has observed, callus formation does not necessarily precede or even accompany root formation. Conditions favoring callus development in cuttings favor root formation also, and conditions that hinder or inhibit the former process will usually check the latter. It is true further that if there is insufficient food for vigorous callus production there is a corresponding deficiency for root formation. Vigorous callus development, therefore, is merely an indication that the cutting is in good condition and is well supplied with food, and that the external conditions are favorable for root formation.

In the course of the present investigation it has been shown that immature cuttings of Ligustrum and herbaceous cuttings of tomato, if placed in sugar solutions for a limited time, will absorb sugar from sucb solutions in sufficient quantities to increase root growth. It has been shown also that if such cuttings are left continuously in the sugar solutions, the root formation is largely suppressed. This inhibition is explained as being due, not to the sugar directly; but to the toxic substances formed. as a result of bacterial or fungous action, or to a lessening of the oxygen content coupled with an increase in carbon-dioxide content. As a genera] rule, propagators are careful to exclude all easily decomposed organic matter from the medium in which the cuttings are to be grown. The explanation usually given for this practice (Bailey, 1913:54) is that the presence of such organic matter supplies a medium in which fungi can grow, and therefore the plants are more liable to damping-off. From the 
results found in the present work, it would seem more probable that the organic matter is acted upon by microorganisms, which results in a decrease in the oxygen supply, an increase in carbon dioxide, and the production of toxic or inhibiting by-products. Each factor enhances the inhibiting effect of the others, and the cuttings are thereby killed or weakened and are then attacked by the fungi.

It has been shown further that the presence of nutrients has a detrimental effect on woody cuttings, and that an increase in concentration of a nutrient solution distinctly reduces growth. This offers another suggestion as to the value of sand as a medium for starting cuttings. Such a medium has, as a rule, less soluble nutrients, is better aerated, and is less likely to contain easily decomposed organic matter, than ordinary soiil.

\section{SUMMARY}

1. The experiments conducted during the course of the present investigation show that treatments with potassium permanganate may result in a very marked increase in root growth of various woody cuttings. Five possible explanations for this stimulation have suggested themselves to the author. These are: (1) that the treatment causes a change in the nature of the food supply of the twig; (2) that it affects the rest period of the cuttings, serving to start growth earlier and thereby causing an apparent stimulation of root growth; (3) that it upsets the balance of food supply between the tops and the roots in favor of the latter; (4) that it retards or inhibits growth of microorganisms; (5) that it increases respiratory activity by catalytically hastening oxidation. The results obtained show that the last of these is the most probable explanation. The others may in some cases be of importance in explaining the rooting of cuttings, but the stimulation by potassium permanganate cannot be fully explained in such ways.

2. Root growth is largely independent of the rest period, for it appears that only the buds, not the whole stem, assume the resting condition.

3. Manganese dioxide, manganese sulfate, aluminium chloride, ferric chloride, ferric sulfate, boric acid, and possibly phosphoric acid, may at times show a slight stimulating effect on the rooting of cuttings.

4. Nutrient solutions are, as a rule, injurious to root growth in cuttings. 
5. Immature twigs can be caused to absorb cane sugar and store it in such form as to be available as a food supply for increased root development.

6. Mature twigs are but slightly benefited, or may even be somewhat injured, by treatment with cane sugar.

7. As a result of placing the base of a cutting in a sugar solution for a short time, the terminal bud of the twig fails to develop in a normal manner and the lower buds form shoots instead.

8. Any injury accompanying treatment with sugar is due, not directly to the sugar, but to the resulting products formed by bacterial or fungous action.

\section{ACKNOWLEDGMENT}

The work reported in this paper was conducted in the Laboratory of Plant Physiology at Cornell University, under the direction of Professor Lewis Knudson. The writer is greatly indebted to Dr. Knudson for many helpful suggestions offered in the preparation of the manuscript. 


\section{BIBLIOGRAPHY}

Acton, E. Hamilton. The assimilation of carbon by green plants from certain organic compounds. Roy. Soc. London. Proc. 47:150175. 1890 .

Agulhon, H. Emploi du bore comme engrais catalytique. Acad. Sci. [Paris]. Compt. rend. 150:288-291. 1910.

Ames, J. W., ANd Boltz, G. E. Tobacco. Influence of fertilizers on composition and quality. Ohio Agr. Exp. Sta. Bul. 285:173-221. (Reference on p. 179.) 1915.

Appleman, Charles O. Biochemical and physiological study of the rest period in the tubers. of Solanum tuberosum. Bot. gaz. 61:265-294. 1916.

BaIley, L. H. Cuttage. In The nursery-book, p. 44-72. 1913.

Balls, W. Lawrence. Temperature and growth. Ann. bot. 22:557591. 1908.

Bertrand, G. Sur les rapports qui existent entre la constitution chimique des composés organiques et leur oxydabilité sous l'influence de la laccase. Acad. Sci. [Paris]. Compt. rend. 122:1132-1134. 1896.

voquées par la laccase. Acad. Sci. [Paris]. Compt. rend. 124:10321035. 1897.

\section{Revue sci. 49:673-680. 1911.}

Bоенм, Jos. Uber den Einfluss der Kohlensäure auf das Ergrünen und Wachsthum der Pflanzen. K. Akad. Wiss. [Vienna], Math.-naturw. Cl. Sitzber. 68 (1873):171-184. 1874.

\section{9-54. 1883.}

Boussingault, -, and Lewy, - Mémoire sur la composition de l'air confiné dans la terre végétale. Acad. Sci. [Paris]. Compt. rend. $35: 765-775.1852$.

Brenchley, W. E. The influence of copper sulphate and manganese sulphate upon the growth of barley. Ann. bot. 24:571-583. 1910.

Effect of manganese compounds. In Inorganic plant poisons and stimulants, p. 78-92. Cambridge Agr. Monographs. 1914. 
The effect of the concentration of the nutrient solution on the growth of barley and wheat in water cultures. Ann. bot. 30:7790. 1916.

Bunzeld, Herbert H., and Hasselbring, Heinrich. The supposed action of potassium permanganate with plant peroxidases. Bot. gaz. $63: 225-228.1917$.

Cannon, W. A., and Free, E. E. The ecological significance of soil aeration. Science n. s. 45:178-180. 1917.

Chapin, Paul. Einfluss der Kohlensäure auf das Wachsthum. Flora $91: 348-379.1902$.

Corbett, L. C. The development of roots from cuttings. In Report for the Department of Agriculture and Horticulture. West Virginia Agr. Exp. Sta. Ann. rept. 9 (1896):196-199. 1897.

Dachnowski, Alfred. The effects of acid and alkaline solutions upon the water relation and the metabolism of plants. Amer. journ. bot. $1: 412-439.1914$.

Fatvre, Ernst. Growth of cuttings. Gard. chron. 1871:969. 1871.

Harris, Frank S. The effect of soil moisture, plant food, and age on the ratio of tops to roots in plants. Amer. Soc. Agron. Journ. 6: 65-75. 1914.

Hart, E. B., and Tottingham, W. E. Relation of sulphur compounds to plant nutrition. Journ. agr. res. 5:233-250. 1915.

HowaRD, W. L. An experimental study of the rest period in plants. Pot grown woody plants. Univ. Missouri Agr. Exp. Sta.' Research bul. 16:1-27. 1915 a.

An experimental study of the rest period in plants. PhysioMissouri Agr. Exp. Sta. Research bul. 21:1-72. $1915 \mathrm{~b}$.

Iwanofr, Leonid. Uber die Wirkung der Phosphate auf die Ausscheidung der Kohlensäure durch Pflanzen. Biochem. Ztschr. 25:171-186. 1910.

Iwanofr, Nicolaus. Die Wirkung der nützlichen und schädlichen Stimulatoren auf die Atmung der lebenden und abgetöteten Pflanzen. Biochem. Ztschr. 32:74-96. 1911.

KaStLE, J. H. The oxidases and other oxygen-catalysts concerned in biological oxidations. U. S. Hygienic Laboratory (Public Health and Marine-Hospital Service). Bul. 59:1-164. 1910.

Kelley, W. P. The function and distribution of manganese in plants and soils. Hawaii Agr. Exp. Sta. Bul. 26:1-56. 1912. 
Kidd, Frankin. The controlling influence of carbon dioxide in the maturation, dormancy, and germination of seeds. Roy. Soc. London. Proc. 87 в :408-421, 609-625. 1914.

KLEBS, GEORG. Willkürliche Entwickelungsänderungen bei Pflanzen, p. 1-166. (Reference on p. 101-104.) 1903.

Knight, Thomas ANDRew. Account of some experiments on the ascent of the sap in trees. Roy. Soc. London. Philosoph. trans. 1801:333353.1801.

On the origin and formation of roots. Roy. Soc. London. Philosoph. trans. 1809:169-176. 1809.

KNUDSon, Lewis. Influence of certain carbohydrates on green plants. Cornell Univ. Agr. Exp. Sta. Memoir 9:1-75. 1916.

Küster, Ernst. Bedingungen der Callusbildung. In Pathologische Pflanzenanatomie, p. 167-171. 1903.

LAU, E. Beiträge zur Kenntnis der Zusammensetzung der im Ackerboden befindlichen Luft. Inaug. Diss. Rostock. (Cited in Exp. sta. rec. 20:817. 1909.) 1906.

LAwEs, J. B. Agricultural chemistry. Turnip culture. Roy. Agr. Soc. [England]. Journ. 8:494-565. (Reference on p. 527.) 1847.

Lipman, Chas. B., and Wilson, Frank H. Toxic inorganic salts and acids as affecting plant growth. Bot. gaz. 55:409-420. 1913.

LOEB, JACQUES. Rules and mechanism of inhibition and correlation in the regeneration of Bryophyllum calycinum. Bot. gaz. 60:249-276. 1915.

Loew, Oscar. On the treatment of crops by stimulating compounds. Tokyo Imp. Univ., Coll. Agr. Bul. 6:161-175. 1904-05.

Loew, O., AND SAWA, S. On the action of manganese compounds on plants. Tokyo Imp. Univ., Coll. Agr. Bul. 5:161-172. -1902-03.

McHargue, J. S. The occurrence and significance of manganese in the seed coat of various seeds. Amer. Chem. Soc. Journ. 36:25322536. 1914.

Meyer, Arthur. Bildung der Stärkekörner in den Laubblättern aus Zuckerarten, Mannit, und Glycerin. Bot. Ztg., 44:81-88, 105-113, 129-137, 145-151. 1886.

Micheels, Henri. Sur les stimulants de la nutrition chez les plantes. Soc. Roy. Botanique Belgique. Compt. rend. 42:233-239. 1905. 
Micheels, H., And De Heen, P. Action de la solution collö̈dale d'étain sur des graines en germination. Acad. Roy. Belgique, Cl. Sci. Bul. 1905 : $310-318.1905$.

Note au sujet de l'action stimulante du manganèse sur la germination. Acad. Roy. Belgique, Cl. Sci. Bul. 1906:288-289. 1906.

Polle, R. Über den Einfluss verschieden hohen Wassergehalts, verschiedener Düngung und Festigkeit des Bodens auf die Wurzelentwicklung des Weizens und der Gerste im ersten Vegetationsstadium. Journ. Landw. 58:297-344. 1910.

Rusche, Albert. Beeinflussung der Keimfähigkeit verschiedener Kulturpflanzen durch Salzdïngung. Journ. Landw. 60:305-365. 1912.

Russell, Edward J. Soil conditions and plant growth, p. 1-168. (Reference on p. 36.) 1912.

Saussure, ThÉod. DE. Influence du gaz oxygène sur le bois mort. In Recherches chimiques sur la végétation, p. 147-152. 1804.

Schreiner, Oswald, Sullivan, M. X., and Reid, F. R. Studies in soil oxidation. U. S. Bur. Soils. Bul. 73:1-57. 1910.

Shedd, O. M. The relation of sulfur to soil fertility. Kentucky Agr. Exp. Sta. Bul. 188:593-630. 1914.

Sim, T. R. Propagation of trees by means of cuttings. Natal agr. journ. and mining rec. 7:247-258. 1904.

Simon, S. Untersuchungen über das Verhalten einiger Wachstumsfunktionen sowie der Atmungstätigkeit der Laubhölzer während der Ruheperiode. Jahrb. wiss. Bot. 43:1-48. 1906.

Skinner, J. J., ANd Reid, F. R. The action of manganese under acid and neutral soil conditions. U. S. Dept. Agr. Bul. 441:1-12. 1916.

Sorauer, Paul. What rules should be followed in striking cuttings? In A popular treatise on the physiology of plants, p. 172-183. (Translated by F. E. Weiss.) 1895.

STILES, WALTER. On the relation between the concentration of the nutrient solution and the rate of growth of plants in water culture. Ann. bot. 29:89-96. 1915.

Stoklasa, Julius, and Ernest, Adolf. Beiträge zur Lösung der Frage der chemischen Natur des Wurzelsekretes. Jahrb. wiss. Bot. 46:55102.1908.

Wilcox, E. V. Pineapples. In Summary of investigations. Hawaii Agr. Exp. Sta. Ann. rept. 1910:14-16. 1911.

Memoir 13, Chlorophyll Inheritance in Maize, the preceding number in this series of publications, was mailed August 31, 1918. 







